\title{
Encouraging Software Reuse
}

Mark A. Lemley

David W. O'Brien

Reprinted from the Stanford Law Review

Volume 49, No. 2, January 1997

Q 1997 by Mark A. Lemley and David W. O'Brien 


\title{
Encouraging Software Reuse $†$
}

\author{
Mark A. Lemley* \& David W. O’Brien**
}

Over the last fifieen years, the primary means of legal protection for com puter software has shified from copyright to patent. In this article, Professor Mark A. Lemley and David W. O'Brien argue that one unanticipated beriefit of this trend may be to encourage software reuse. They note that computer programmers traditionally reinvent software components, coding each new program from scratch rather than buying and reusing existing components. This gram from scratch rather than buying and reusing existing components. This
inefficient process operates in stark contrast 10 common practice in other engineering disciplines. Lemley and $O^{\prime} B$ rien argue that copyright law encourages reinvention and discourages the development of a market for tradeable software components because it allows competitors to appropriate the value of a new software invention without payment to the original inventor, but forbids competitors from copying the computer code implementing that invention. As a result, competitors copy others: inventions and ideas but write their own code to avoid infringing copyright. By contrast, patent protection forces competitors manufacturing any product incorporating the invention to obtain a license from the patent owner. Lemley and $O^{\prime}$ Brien mainsain that the trend coward reliance on parent law may lead ideas and their implementing code, paving the way for an expansion of trading and reuse of software components.

I. INTRODUCTION $\ldots \ldots \ldots \ldots \ldots \ldots \ldots \ldots \ldots \ldots \ldots \ldots \ldots \ldots \ldots \ldots, 256$

II. Software Reinvention and Reuse.................... 259

A. The Inefficiency of "Reinventing" ................ 260

1. Direct costs of redesign and redevelopment........ 261

2. Indirect cosis of errors and bugs................ 262

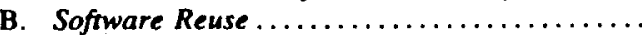

1. Reuse benefits. ............................. 264

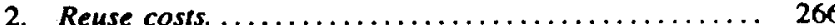

3. Reuse economics and the producer perspective........ 267

III. Investment in Reusable SortwaRe Components .......... 268

A. The Public Goods Problem...................... 268

† Copyright 1997, Mark A. Lemley and David W. O'Brien. Fish \& Richardson PC., Austin, Texas.

** Associate, Skjerven, Morrill, MacPherson, Franklin \& Friel L.L.P., Austin, Texas.

Portions of this paper were presented in Henry Hu's seminar on financial and industrial innovation at the University of Texas School of Law in 1994, and we are grateful for his assistance there. We have also benefited from comments made by David Anderson, Cindy Estlund, Rose Hagan, Marci Hamilion. Doug Laycock. David McGowan, Neil Netanel, Rob Merges. Pam Samuelson, Jay Westbrook, the editors of the Stanford Law Review, and participants in a faculty colloquium at the University of Texas School of Low. 
B. Access Restrictive Methods for Appropriating Returns.... 270

1. Trade secret protection. ....................... 271

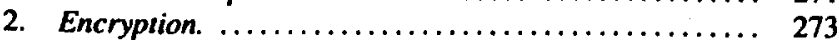

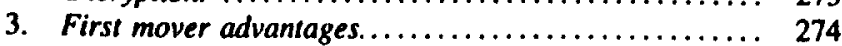

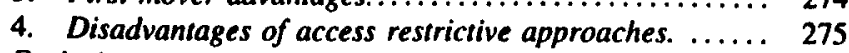

C. Exclusive Rights Under the Federal Intellectual Property

Laws ......................................... 276

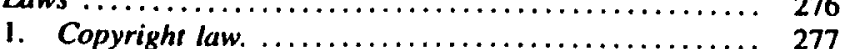

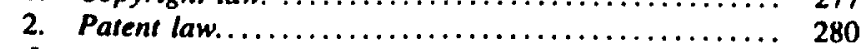

IV. The Impact of Intel.lectual. Property Rights on

Transactions in Software Components ............... 284

A. Economics of Software Components Markets ........... 285

B. The Impact of Legal Rules ........................ 290

C. Software Patents and Components Markets ............... 294

D. The Outlook for Developing a Reusable Component

Market........................................... 299

V. Conclusion $\ldots \ldots \ldots \ldots \ldots \ldots \ldots \ldots \ldots \ldots \ldots \ldots \ldots \ldots, 304$

I's like musket making was before Eli Whitney. . . . Before the industrial revolution, there was a nonspecialized approach 10 manufacturing goods that involved very little interchangeability and a maximum of craftsmanship. If we are ever going to lick this software crisis. we're going to have to stop this hand-to-mouth, every-programmer-builds-everything-from-the-ground-up. preindustrial approach.

\section{INTRODUCTION}

Software developers routinely reinvent the software equivalents of the wheel and the transistor every time they develop a new program. ${ }^{2}$ By contrast more traditional scientific and engineering disciplines, such as mechanical and I. W. Wayt Gibbs, Soffware's Chromic Crisis. Sc1. AM., Sept. 1994, at 86, 87 (quoting Professor
Brad J. Cox of George Mason University).

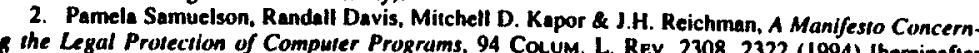
Ing the Legal Protection of Computer Programs, 94 CoLum. L. Rev. 2308. 2322 (1994) (hereinafier Typically a progrem of the Manifesto explain:

Typically. a programmer writes every line of code afresh, no matter how lorge the program is,
or how common its tasks. To perceive the impact of this lack of sundent bullting

imagine trying to design on entire car in complete detail, down to the last fastener, without being able to assume the existence of any siandard parts at all (not even nuis, bolts, or screws) Id. (citations omitted). With classic understetement, the authors note that "(I)his is not a desirable state of affairs." Id. at $2322 \mathrm{n.41}$. One cause of this problem is the "not-invented-here" syndrome, which refers to the general unwillingness of software developers to use software components designed and implemented by others. John Favero. What Price Reusabilisy? A Case Siudy. ADA LeTters, Sprin 191, at 115. 116. In a Usenet newggroup discussion about sofiware engincering, one engineer argued it is not feasible for an electrical entineer it is not feasible for an electrical engineer designing a circuil bosnd to make his own integrated circuits. from scraich: "This lack of conceptual barrier allows sofiware developers to reinge new components easily, where this is well nigh impossible for the [eloctrical engineerl." Usenet post the wheel very

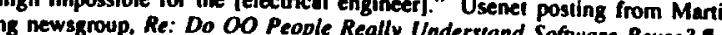
(Jan. 7. 1995) (on file with the Sianford Law Review).

electrical engineering, build upon existing components, structures, and methods with attributes and limitations widely known within these fields. These components, structures, and methods are incrementally improved, reused, and improved again in a constant cycle of innovation. As a result, a robust marke exists for components such as gears, transistors, and standand cell semiconductor designs, whereas there is currently little, if any, market for software components. ${ }^{3}$ Many software cost and reliability problems stem from this software reinvention culture. In the words of one computer science professor, softwane development "needs to become more of an engineering discipline. ... It's treated too often as an art form ...."4

Economic and historical factors have shaped the development of the current culture in which reinvention prevails over reuse. Because software represented only a small part of early computer systems, ${ }^{3}$ protection of computer software was lax. In fact, computer vendors often treated sofiware as merely incidental to the sale of the "real" product-the handware. Although the value of software rose to forty percent of the value of the computer system by the $1960 \mathrm{~s}^{7}$ computer manufacturers continued to bundle hardware, software, operating systems, and technical assistance into an integrated package with a single overall price." "Custom" software for more specific needs was normally developed in-house by the purchasers."

The legal environment has also played a role in cementing the culture of software reinvention. Intellectual property protection for computer software developed slowly, and initially emphasized trade secret laws against misappropriation and copyright prohibitions against the literal copying of computer

3. See Gibbs, supra note 1, at 93-94 (characterizing current software development practices as unsystemaric and describing a Nacional Institute of Standards and Technology ("NIST") program aimed 1994. at 99 (describing the Oct. 24. 1994 NIST announcement of a "five-year. S1 SOm project to create sofiware-component induatry" including the development of "new 'anchitectures', 'semantics', and 'for mal languages' "). But of. Keith Stephens \& John P. Sumner, Soffware Objects: A New Trend in Pro gramming and Soffware Palenis, 12 SANTA CLARA Compurten \& HIOH TECH. L.J. I. 29 (1996) (concluding that existing object-oniented programming techniques allow software engineers to build (a) new program).

4. Andrew Pollack. Transforming the Decade: 10 Critical Technologies: Software Writing from an Art To a Science, N.Y. Times, Jan. I. 1991, he 39 (quoting Victor R. Basili, Prolessor of Computer Science at the University of Maryland).

5. See Charues H. Fenouson \& Charies R. Monks. Computen Wars: How the West Can WiN in A Posr-1BM Woreo 7 (1993) ("Only about 8 percent of the value of the earliest aystems wes accounted for by software.")

6. See Thomas P. Burke. Note, Software Pasent Provection: Debugsing the Current System. 69 Notre Dame L. Rev. 1115,1126 (1994) ("Much as car dealers used 10 throw in floor mats and a full tank of gas. hardware vendors would include the software 10 make their systems operational.")

7. See Ferouson \& Monrus, supra note S, at 7 .

8. See Thomas J. Watson, Ja \& Peter Petree, Pather, Son, Co Co.: My Life at IBM and Berond 380-81 (1990) (describing IBM"s "bundling" in which compuret sofware, hardware, training. mainienance, and rechnical essistance were all sold for a single price).

9. See Burke, supra note 6, at 1 I 26 (explaining that business applications that didn't come bundlad with computer hardware were typically wrinen in -house). 
code. 10 Trade secret law remained the dominant form of legal protection of software through the mid-1970s." Then, in 1980. Congress amended the Copyright Act to expressly include software, and copyright law became the dominant basis for protection throughout the 1980s.12 More recently, patent law arrived on the software scene. ${ }^{13}$ Although by 1981 court decisions clearly established the patentability of certain software-related inventions, 14 and the U.S. Patent and Trademark Office ("PTO") issued the first widely acknowledged pure software patent in 1983, is it has only recently been widely recognized that patent laws can provide protection for computer software. 16

Both trade secret and copyright law offer effective protection for the tangible embodiments of computer software-the computer code itself. However they both offer only extremely limited protection for the underlying techniques and ideas embodied in the software. For example, the copyright statute specifically excludes from protection "any idea, procedure, process, system, method of operation, concept, principle, or discovery, regardless of the form in which i is described, explained, illustrated, or embodied in such work." 17 Further, both

10. The term "compulter code" includes both source (human readeble) and object (machine readeble) code. For a discussion of the role of trade secret and copyright protections, see text accompanying
notes 99.112 . 135-161 infra. 11. See David Bender.

Reffection on Siffware Protection Over the Years, 16 RuTe More They Stay the Same: An Unhurried (I) (In the ares of sofitware profection, the 1970s was the decade of iracte secret litigation"). 12. See Act of Dec. 12. 1980, Pub. L. No. 96-517. 10(0), 94 Stat. 3015, 3028 (1980) (codified amended at 17 U.S.C. 8101 (1994)) ("A compuler program" is a sel of stotements or instructions to be used directly or indirectly in a computer in order to bring about a certain resul!."); see also \$10(b), 94 Siat. at 3028 (codified at 17 U.S.C. 117 (1994)) (allowing copying of computer programs for archival or use purposes). In addition, the 1976 Copyright Act Irested sofiwere programs as literary works. Congress enacted an interim section, Pub. L. No. 94-553, ch. 1. 117, 90 Stat. 2541. 2565 (1976), New Ting copyrighiability of computer programs pending the outcome of a report by the Commission on U.S.C.C.A.N. 5659, 5667. 5731 .

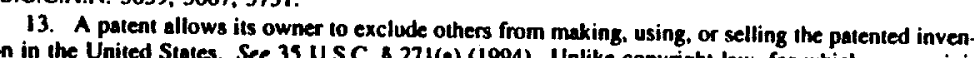
lion in the United Stolles. See 35 U.S.C. 271 (a) (1994). Unlike copyright law, for which mere originality is the threshold requirement, the availability of patent protection is fimited by the staturory 14. See Diomoly and nonobviousness. See 3S U.S.C. 69 102, 103 (1994).

synthetic rubber was patentable subject matter deapite use of (1981) (holding that a process for curing

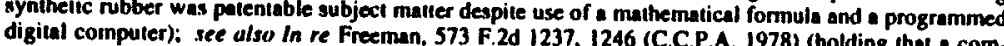
puter-based systern for lypesenting was patentable subject matter despite use of (holding that a com

15. See United Sutes Patent No. 4.398.249 (entitled Process and Apparatus for Converting). Sounce Program into an Object Program). The original patent application was filed on August 12. 1970.
but the patent was not issuod until August 9. 1983.

16. See, e.g. In re Alappan, 33 F.3d IS26, 1542.45 (Fed. Cir. 1994) (en banc) (holding that patentability is not precluded even if program includes mathematical subject matter); see also in re Trovato 60 F.3d 807 (Fed. Cir. 1995) (en banc) (per curiam) (vacating and remanding for reconsideration panel decision that rejected patent application for computer process using a mathematical algorithm). 17. 17 U.S.C. 102 (b) (1994). This section codifies what is known as the idea-expression dichotony. See Whelan Assocs. v. Jaslow Dental Lab., Inc., 797 F.2d 1222, 1234 (3d Cir. 1986) ("The legislative history of this section, edopred in 1976, makes clear tha1 102 (b) was intended to express the ides-expression dicholomy."). cert. denied 479 U.S. 1031 (1987); see also Julie E. Cohen, Reverse Engineering and the Rise of Electronic Vigilannism: Inrellectual Property Implications of "Lack-Out" evolved in early cases concerning the scope of copynith proting how the idea-expression dichotomy trade secrecy and copyright law operate to channel innovation in directions which are not always productive from an engineering or economic standpoint.

As a result, from the beginning of the software era and through much of the 1980s, the formative years for many of today's software professionals, copyright and trade secret law defined the rules for software innovation. While new programming structures and techniques spread quickly as programmers moved from job to job. ${ }^{18}$ copyright law punished the transfer of actual code implementations of these structures and techniques. Software developers routinely appropriated others' successful software innovations, but the actual code implementing the innovation was a dangerous commodity. Rather than risk liability for copyright infringement, programmers routinely sacrificed the benefits of successive refinements and bug fixes in existing code in favor of recoding the software themse'ves from scratch.

While we acknowledge the importance of historical and cultural factors that encouraged software reinvention in this article we focus on the ways in which legal and economic incentives for software innovation influence the tradeoff between reinvention and reuse. We' suggest that successful development of a market for reusable software components is most likely under a legal regime which provides strong protection for innovative components but little on no protection for the interoperability elements of programs and the interconnection of components in particular ways. Recent developments suggest that intellectual propeny law is moving in this general direction, emphasizing strong patent protection for components and weakening copyright protection for program interfaces and interoperability elements. This trend should encourage the development of a reusable software market.

In Part II, we examine the costs associated with software reinvention and evaluate the benefits of software reuse in both internal and external reuse markets. We conclude that software reinvention is generally inefficient. In Part III, we analyze the role of law in shaping the development of the software market. We also examine various possible methods for ensuring adequate economic incentives to invest in reusable software, and provide a brief overview of the legal protections available to computer programs. Finally, in Part IV, we argue that patent protection is better suited than copyright and trade secrecy to a software components-based market. We explore the implications of the current shift from copyright to patent protection in some detail, suggesting how the law might develop to encourage software reuse.

\section{Software Reinvention and Reuse}

The terms "software reinvention" and "software reuse" are stylized descriptions of different organizational approaches to software engineering. Software reuse has become a buzz-word in the government-sponsored software commu-

\footnotetext{
18. See Burke, supra nole 6, al 1126 ("new programming techniques were quickly spread by
} 
nity. 19 In addition to a variety of government research and development programs focused on reuse, the federal government recently undertook an ambitious program to create large national software asset repositories, ${ }^{20}$ and in 1994 the National Institute of Standards and Technology ("NIST") announced a 5-year, \$150 million program to develop a nationwide external market for tradeable software components. ${ }^{21}$

In contrast, the term "software reinvention" tends to represent all that is inefficient and parochial about the software development process of handcrafting solutions. Most people agree with the simplistic assertion that reuse is good and reinvention bad. However, reuse and reinvention are really only polar extremes on a continuum of approaches. In this Part, we attempt to characterize the poles of this continuum and clarify the role that various software innovation incentives play in the reinvention/reuse tradeoff.

\section{A. The Inefficiency of "Reinventing"}

Software reinvention unnecessarily incurs substantial costs by duplicating effort and failing to incorporate the lessons of past mistakes and inefficiencies into future software designs and implementations. These costs include both the direct costs of designing, coding, debugging, documenting, and supporting reinvented software, and the indirect costs associated with bugs and interoperability problems. Precise quantification of such costs is nearly impossible, 22 but most experts agree that the aggregate costs are substantial. ${ }^{23}$ Rough estimates place the annual aggregate cost of reinvention at between $\$ 2$ billion and $\$ 100$ billion. ${ }^{24}$

19. See U.S. Gov'T Accountino Opfice. Pub. No. B-251542, Sortwake Reuse: Manon Issues Need to Be Resolved Beroere Benzets Can Be Achieved 19-20 (1993) (hereinafier GAO Repor ON Sortware Reuse) (discussing \& Defense Depantment software reuse initiative involving three major reuse programs: the Defense Advenced Research Projects Agency's Sof tware Technology for Adapteble, Reliable Systems ("STARS"), the Air Force's Central Archive for Reusable Defense Softwart 20. One example is the Assert Source Systems Agency': ("DISA") Software Reuse Program). 20. One example is the Asset Source for Soltware-Engineering Technology ("ASSET"), which is information describing ASSET resources is availabie on the World Wide Web. See ASSET Wetcered Page (last modified Nov. II, 1996) <hnp://source.Assel.com/asset. hemls.

21. See Sitich Ups: Sogftware, supra note 3. In 99 (describing NIST project)

22. See William B. Frakes \& Sadahiro isoda, Success Factors of Systematic Reuse, IEEE Sortwark, Sept. 1994, at 15, 16-17 ("Reliable data on how much this (reuse) costs and the benefits organization will derive is insufficient."). Even if researchers had access to life cycle financial records for all U.S. soffware development projects, they would still have difficulty quantifying these costs because of the lack of an adequale control group.

23. See GAO REPort ON SOFTwane Reuse, supra note 19, at I (noting that the Department of Defense estimates that creation and upkeep of its software costs more than \$24 billion annually and asserning that software reuse "offers the potential to greatly reduce the time, cost, and effort needed to elop and maintain high quality software")

software enterprises, which are not necessarily represenolated from audit data for extremely large-scale software system. See, e.8. J. Margono \& L. Lindsey, Software Reuse in or complexily of the average vanced Aulomation Sysiem, in Proc. Of THE SYmposium or Sortwe in the Air Traffic Control Ad(1991). Differences in scale and complexity between sofitware engineering effons render the eccuracy of such exirapolated entimater questionable. See, e.R.. Gitbs, supra note 1 . 89 (utributing the ecturacy of ing cost of the new air traffic control sysilem to the need to rewrite code). On the other hand, progrem.

\section{Direct costs of redesign and redevelopment.}

While accurate estimation of the direct costs of designing, coding, debugging, documenting, and supporting reinvented software is difficult, we can gain some insight from examining the Federal Aviation Administration's ("FAA") Advanced Automation System ("AAS"). The AAS was the central componen of an effort to replace the nation's increasingly obsolete air traffic control system. The software aspect of the program was estimated to require the design and development of more than a million lines of code-much of it complex real time, safety critical code. ${ }^{25}$ The FAA originally estimated that the AAS software would cost $\$ 500$ per line of code, but in 1994 was actually paying \$700-900 per line. ${ }^{26}$ As a result, redesigning, recoding, debugging, and documenting even only 10 percent of the AAS code would have cost tens of millions of dollars. These costs are not atypical for large, mission-critical system developments.

Even much smaller consumer-oriented projects, while not involving such extraordinary expenses, incur significant reinvention costs. For example, reuse studies at Hewlett-Packard ("HP") compared the productivity rate of intemal software engineering groups before and after the institution of concerted internal software reuse programs. ${ }^{27}$ The studies found that reuse significantly enhanced programmer productivity. Before instituting the reuse program, HP's Software Technology Division indicated an average productivity rate of 700 noncomment source statements ("NCSS") per engineering month for software developed from scratch. The productivity rate improved to 1100 NCSS per engineering month (a 57 percent increase) when the division implemented the reuse program. ${ }^{28}$ HP's Technical Graphics Division reported a similar experience. ${ }^{29}$ For a typical 50,000 NCSS software project, such productivity differences can translate into savings of hundreds of thousands of dollars. ${ }^{30}$

mers develop most large-scale nofiware systems from detailed design specifications and less plans; these nigorous design lochniques may partinlly offset scale and complexity differences. However. any estimate of the magnitude of such an effoci would be entirely speculative. Rocognizing these limitations, we present cost
tify its scale.

25. See generally Gary Stix. Aging Aimays. ScI. AM., May 1994, at 96, 99-101 (describing the problems that accompany the $\$ 36$ billion AAS revision effort). The FAA announced its abandonment of the AAS project in 1994, but since then has undernaken a more modest projoct. See Marthew $L$. Wald, Flight to Nowhere: A Special Repon: Ambirious Update of Air Navigation Becomes a Fiasco. N.Y MES, Jan. 29. 1996, \& A

26. See Gibbs, supra note 1 , at 89 . Large scale projects such as the AAS typically involve hun drods of thousands of lines of code. See also Mark Lewyn, Flying in Place: The FAA's Air.Control computer code).
27. See Wayne C. Lim, Effecis of Reuse on Ouulty Productivity and Economics.

Whne C. Lim, Effects of Reuse on Quality. Productiviry and Economics, IEEE SOPTWARE. Sept. 1994, at 23 (reporting the results of case studies involving HP's Software Tochnotogy See idaphics Divisions

29. See id. (reporting a $40 \%$ improverment per engineering month from 500 NCSS for new code to 700 NCSS for a product made up of $31 \% 0$ reused code).

30. For this calculation. we assume that the amrount expendad by a software company for one programmer in a typical engineering monih is 510,000 . Including employee benefits and overtiead ex- 
Today, even consumer products rely on increasing quantities of software. Television sets may incorporate 25,000 lines of software, and even a simple electric shaver can embed 100 lines. $^{31}$ Power trains in new General Motors cars contain roughly 30,000 lines of code. ${ }^{32}$ Although they are difficult to quantify precisely, ${ }^{33}$ the private costs associated with the practice of software reinvention are substantial simply because so much code needs to be rewritten.

\section{Indirect costs of reinvention: errors and bugs.}

A system that rewards reinvention rather than reuse also has substantial social costs. The social costs incurred by reinvention rather than reuse include the indirect costs imposed by errors and bugs that go undetected after the implementation of a program. Software reinvention imposes indirect and consequential costs because newly created software modules exhibit much higher error rates than software components used multiple times. ${ }^{34}$ Some of these costs are predictable; the costs of identifying and correcting design and coding errors (bugs) appear privately as increased production costs and are passed on to the public as higher prices. Other costs are not predictable; latent, undiscov ered bugs, and the delays associated with identifying and correcting such errors (debugging), can result in consequential losses. For an example of a project paralyzed by bugs, consider Denver's new intemational airport, which sat idle for sixteen months after its projecled opening date due to bugs in its baggage handling software. ${ }^{35}$ The delay forced the city to pay more than $\$ 1$ million per day. ${ }^{36}$ and in August 1994 Denver decided to install a "temporary backup" conventional conveyor belt system. ${ }^{37}$ The backup system itself was only semioperational by January 1995, and estimates of its cost range between \$SO million and \$62.9 million. ${ }^{34}$ Such monumental waste might not have occurred were it not the program's first run. A more troubling problem is that most

71,4 man-months 10 complete a 50,000 NCSS sofiware project. At $\$ 10,000$ per man-month this translates into a lotal expenditure of approximately \$714.000. If programer productivity increnses to 1100 NCSS per month, the tolal cost drops to $\$ 455,000$. Thus, productivity differences like those reponed by Pould translate imto $\$ 259,000$ in savings.

31. See Gibbs, supra note 1, at 88 (reponting 500,000 bytes for televisions and 2000 byres for electric shavers). Although the iransintion from source statements to bytes of executable code may vary grenlly depending on the source lenguage, operating environment, and programning style, a reasonuble

32. See id.

33. See notes $22-24$ supra and accompanying text.

34. See Lim, supra note 27, at 24 (analyzing soffware quality improvements associated with reuse).

35. See Denver Airport Opens, Aniz. Buss. Gazerre, Mar. 2. 1995, al 13; see also, Gibbs, supro note 1, al 86 (discussing delays); Sritch Ups: Suffiware, supra note 3. at 99.

36. See Mark Eddy, Webb Mum on Opening Till August, Denv. Post, June 22, 1994, at BI (exAirpon).

37. Unived to Take over Denver Baggage System, L.A. Times, Aug. 24, 1994, at D2; see also Mark Eddy, Feb. 28 Opening for DIA? Webb's Fund Plea Says Yes, Bur Doubr Lingers, Denv. Post. 38. See Kevin (describing continuing delays and backup system installation)

Systems Work Properly, RockY MTw. News, Jan. 14, 1995, Three Hour DIA Trial Indicates Switching

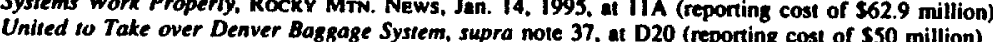

modern safety, energy and transportation systems rely on software. High error rates can be deadly if they are not corrected up front. ${ }^{39}$

Reinvention incurs these indirect and consequential costs each time programmers craft software from scratch. Describing ongoing problems with the FAA's AAS, an internal report complained that "on average every line of code developed needs to be rewritten once."40 Although reused sofiware is by no means bug-free, various studies have shown dramatic reductions in error rates for reused software compared with new code.11 An advantage of reused software is that bugs which are identified during prior use can be avoided or corrected in subsequent uses. For example, in a 1991 study of software developed by its Flight Dynamics Division, the National Aeronautics and Space Administration's ("NASA") Goddand Space Flight Center reponed an 87 percent reduction in error rates when it engaged in a program of software reuse. $42 \mathrm{HP}$ demonstrated similar reductions, reporting a 76 percent reduction from 4.1 defects per thousand NCSS for newly written code to 0.9 defects per thousand NCSS for reused code. ${ }^{43}$ Even considering that reused code must be combined with some newly generated code. HP found that defect rates for programs consisting of combined new and reused code were 51 percent lower than for completely new code.4 In essence, sofiware reuse allows software developers to capitalize on mature, rather than unproven, designs and implementations.

The problem of errors in software grows at a nonlinear rate as the size and complexity of new software programs increases. ${ }^{45}$ Several studies indicate that smaller programs are le is prone to defects than larger ones. ${ }^{46}$ Not only do smaller programs have fewer total defects, but they also have fewer defects per line of code. ${ }^{47} \mathrm{It}$ is therefore harder to write a 100.000 line program without defects than it is to write ten 10,000 line programs without defects. ${ }^{48}$ Large new programs thus have two different problems: new code has more errors than reused code, and large programs have more errors per NCSS than small pro-

39. See Evan I. Schwart, Trust Me, I'm Your Soffware, Discoven, May 1996, a1 79, 81 (arguing that the solution to the software reliability problem is to "cake steps to ensure that the sofiware is right in the first place and to prove that it works mathematically").

40. Gibbs, supra note 1, at 89 (quooting the intemal FAA repon).

41. See. e.g.; GAO REPONT ON SOFTwARE REUSE, supre mole 19. al 6 (reporting the results of a 1991 study by NASA's Sofiware Engineering Laboratory): see also Lim. supro note 27. at 24-26 (reporing the resulis of two HP studies).

42. See GAO REPORT ON SOFTWARE Reuse supra note 19, at 5.6 (reporing a reduction from 3.9

43. See Lim, supra note 27, at 24 (reporting results for HP's Software Technolugy Division)

45. See Kevin Keisy, Out of Contmol: The New Bioloor or Machines, Social. Systems amp THE ECONOAnic Wored 194-95 (1994) (describing the difficulty of controlling complex and unpredictable sofiware systems)

46. See id. at 197.99 (citing examples); see also Jay Dratter, Jr., Microsofi as an Antisrust Torget: IBM in Soffware?, 25 Sw. U. L. Rev. 671,737 (1996) (noting that more complex programs coninin greater numbers of emors).

47. See Keu.r. supro note 45 , at 197.

48. For this reason, many programmers advocate the development of smaller "modular" software programs that can be linked logether as noeded. See id. (citing sounces). The current popularity of
object-oriented progremming is one example of this trend. See id. ot 197.98. 
grams. ${ }^{49}$ The current practice of software reinvention is uniquely inefficient because programmers are encouraged to produce monolithic programs containing exclusively new code, rather than reusable, modular programs containing code that was previously written and debugged.

\section{B. Software Reuse}

Software reuse involves integrating software engineering artifacts from ex isting software systems into the design and development of new software 30 Such artifacts may include code, system architecture, documentation, user interfaces, and data. ${ }^{31}$ Reuse takes two forms: opportunistic reuse and systematic reuse. Opportunistic reuse is the ad hoc practice of salvaging code from existing systems and modifying it to serve the design goals of a new program. ${ }^{32}$ Individuals and small software companies routinely practice opportunistic
reuse. ${ }^{53}$

We will focus primarily on the systematic reuse of software components within and across organizations. Systematic reuse creates new applications from software designed to be incorporated and reused within other similar programs. $^{54}$ Systematic reuse therefore demands that programmers undergo what some authors call a "paradigm shift," from the creation of unitary, autonomous systems to the creation of families of interlocking, related systems. ${ }^{35}$

Systematic reuse can be either internal or external. Large commercial organizations such as AT\&T, Digital, HP. IBM, Microsoft, and Motorola glready have internal reuse programs in place. ${ }^{56}$ On the other hand, external reuse is uncommon even in large corporations. ${ }^{37}$ If reuse is to occur across and not only within organizations, this new focus must include the development of a market for software components. In the sections which follow, we discuss the benefits and costs of software reuse.

\section{Reuse benefits.}

Software reuse is no panacea. Indeed, common usage of the term often belies the vast gulf that exists between its promise and actual documented suc

\footnotetext{
49. See id. at 194-97.

50. See Frakes \& Isoda, supra note 22, at is; see also GAO Report on Sortware Reuse, supra

51. See GAO Renont on Sortware Reuse, supra mote 19, at 2; Capers Jones. Economics of Sofiware Reuse. Compuren. July 1994, at 106.07 (identifying ten iypes of sofiware artificts that can be Sused).

2. See GAO REPOnt ON SOFtwARe Reuse, supra note 19, a 3

53. See Frakes \& Isode, supra note 22, at is.

54. See GAO Reront on Sortwake Reuse.

55. See Frakes \& lsoda, supra note 22, at is

56. See id. at 16.

57. Software distribured in the Usenet newsgroups comp.wources includes free source code for a vast amray of programs written by individuals and placed in the public domain. Nonetheless, the comp.sources archives represent. an best, an ad hoc collection of application source code without mainiearchives is of poor quality, and sources are rarely updered with refine there, genenilly soffware in the
}

cesses. ${ }^{38}$ Nonetheless, syc:ematic software reuse can improve the quality of components, increase thu productivity of the creators, and reduce the time to market of the finished product. ${ }^{59}$ It is well known that the quality of code improves over time as bugs in a program are identified and fixed. Reuse facilitates this quality improvement because each piece of code is used over the life of several applications. ${ }^{00}$ Further, computer companies have a greater incentive to catch and remove defects in reusable components, where the cost of debugging is spread over a longer lifetime, than in software that is used once and thrown away. ${ }^{61}$ The dramatic reductions in defect rates reported by HP62 and $\mathrm{NASA}^{\mathbf{6 3}}$ demonstrate that reuse can improve software quality. Finally, software reuse may improve consumer information in the market for software programs. Because the public over time develops a body of knowledge about the accuracy of a particular program or component, reuse of that program or component allows consumers to apply that knowledge instead of forcing them to leam about an entirely new program with each new generation of software. ${ }^{.4}$

Software reuse also improves programmer productivity by reducing the total number of lines that must be coded and by increasing programmers' familiarity with the lines that are written. ${ }^{65}$ HP and NASA reported productivity improvements of roughly 50 percent. 60 The increased productivity initially results from the fact that companies develop fewer programs from scratch, but extends beyond the coding phase to corresponding improvements in documentation, testing, and maintenance productivity. ${ }^{67}$ Both vertical reuse of software components within a particular department and horizontal reuse of software components across a large number of unrelated projects may reduce aggregate labor costs. ${ }^{68}$ Reuse may also reduce labor costs by encouraging internal specialization or by capitalizing on external specialists as sources of reuse components. since specialization tends to increase efficiency. ${ }^{69}$

38. See Frakes \& isoda, supra mole 22 , at is ("The reuse literature is skewed towards reponting successes; failures are largely unreponted."); of. Favaro. supra note 2, at 116.17 (describing human and lechnical difficulties with implementing sofiware reuse).

39. See GAO Reront ON Sortwake Reuse supra note 19, al 5.6 (describing possible improvements available through reuse); see also Lim, supra note 27, at 23.24.

60. See Lim, supra nole 27, at 24.
61. See Id.: see also Mitchell D. Lubars, Affording Higher Rellabiling Through Software Reusability. ACM SIGSOFT SOFTwAite ENoineeruna Nomes, Oci. 1986, at 39, 41 ("If the original coftware was developed to be reusable ... [I the cost of debugging could be amorized among the 62 See iexl poducts.

62. See lext accompanying notes $13-44$ supro.

63. See note 42 supra and accompanying lex

27. at 23 .

65. See id. al 25; see also Pamela Samuelson. Toward a Reform of the Derense Depart No. CMU/SEI-86-TR-1. 1986)

66. See Lim, supra note 27, at 25. (reporting $40 \%$ and $57 \%$ improvements in two divisions); see also GAO RePORT On SOFTwake Reuse, supra note 19, at 6 (reporting a 53\% increase in productivity

67. See Lim, supra nore 27, at 25 ("II)f the reused work products are already documented and 68. See GAO Reroner on koms work in these ancas."

政 4 (describing horizonial use of 69 . See Lim, suprot and merge procedures, which are useful in a wide variery of programs). 
This potential savings in development and testing time not only translates into a reduction in development costs, but also reduces the time-to-market, which is critical to success in the fast-paced software industry. Although few statistics are available, HP's study of reuse in its graphics software division suggested a 42 percent reduction in time-to-market for printer and plotter firmware. ${ }^{71}$

Of course, the aggregated social benefits of software reuse depend on the amount of software reused and on the costs associated with the reuse. David Fisher, director for NIST's software components program, estimates that building only 5 percent of all software from reusable components would save over $\$ 2$ billion per year.71 And whatever the social benefits are, the existence of internal software reuse programs at large commercial organizations such as HP. IBM, and Microsoft suggests that financial incentives for reuse exist at these companies.

\section{Reuse costs}

The creation and maintenance of reusable software components is more costly than the creation of ordinary computer programs. ${ }^{72}$ Some of these addiiional costs result from efforts to create an infrastructure for reuse. Such infrastructure expenses include costs associated with purchasing reusable components from outside a company, establishing libraries and search techniques for cataloging and retrieving components, maintaining and upgrading components, and educating programmers in the culture of reuse. ${ }^{73}$ However, the most important costs are the incremental costs of creating reusable software components and of integrating reused components into new products. Scholars examining the federal government's AAS reuse program have shown that reusable software components cost about twice as much to create as components that will be thrown away. ${ }^{74}$ Other findings suggest incremental cosis for reusable software that are 111 percent 10450 percent of the cost of nonreusable software. ${ }^{75}$ In each case examined. however, the cost of integrating the reusable software component with other software was only a small fraction of the cost of developing and integrating a comparable new component from scratch ${ }^{76}$ Therefore, although it costs more to create reusable components ini-

\footnotetext{
70. See id. it 26 (reporting development time reduction from 36 to 21 months).

71. See Stitch Ups: Suftware, supra note 3, at 99 (quoting David Fisher)

72. See Lim, supra note 27, at 24

73. See id. $124,26-27$

74. See id. at 26; John Margono \& Thomas E. Rhonds, Sofiware Reuse Economics: Cost-Benefit

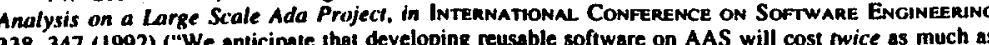
338, 347 (1992) ("We anticipale the 75.

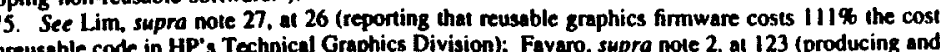
of nonseusable code in HP's Technical Graph of the cost of nonreuseble sof fware).

76. See Lim, supra note 27, at 26 (studing that the cost of creating software from existing components is only $19 \%$ of the cost of reinvention); Margono \& Rhoeds, supra note 74, at 347 ("'the benefits of reniso on AAS have so far outweighed the cosis"); Favero, supra note 2, al 115 (reuse cosis are $10 \%$ 10
} 6.3\% of reinvention cosis).

tially, overall the savings offered by reusable components outweigh the initia cost.

\section{Reuse economics and the producer perspective.}

Commenting on the economics of software reuse, Capers Jones of Software Productivity Research, Inc., put it this way:

[Clonsider what these three activities have in common:

(1) building a 12-meter yacht to compete in the America's Cup.

[2] building a Formula 1 racing car, and

[3] building a software order-entry system.

They all cost more than $\$ 1$ million and for the same reason: Each is a custom product designed and constructed manually by skilled and highly paid craftsmen. ${ }^{77}$

Jones suggests that significant cost reductions for any of these goods requires that manufacturers use standardized, compatible parts rather than custom software development. ${ }^{78}$ In this section, we explore the incentives for software developers to create an external market for standardized components.

From the perspective of the consumer of reusable software components, the source of software components-internal or external-is largely irrelevant as long as the components are of equal quality. From the perspective of the producer, on the other hand, the incentives to create reusable software differ greatly depending on whether the consumer and the producer are part of the same organization. Reuse costs money and produces assets. The potential market return to such an invesiment determines whether it is worthwhile for a developer to create a reusable software component. ${ }^{79}$

If the producer of a reusable software component is also the consumer, the organization's economic return for its investment and efforts can be readily quantified. HP, for example, calculated its return on its reuse programs by estimating the stream of benefits generated by a given reusable component, subtracting the stream of associated costs, and determining the present value of the net benefits (or net costs). ${ }^{80}$ HP's results indicate substantial returns for two reported projects, which have generated net present benefits of $\$ 1.6$ million and $\$ 0.9$ million. ${ }^{81}$ The two projects broke even in their second and sixth years, respectively. ${ }^{82}$ These numbers suggest that internal software reuse is viable in some organizations even without an external market for reusable components. ${ }^{83}$

\footnotetext{
77. Jones, supra note S1, \$1 106

78. See id.: see also lext accompanying notes 1-4 supro.

22, at 17; Lim, supra note 27, \&1 27.28.

80. See Lim, supra note 27, at 27 (applying net present value lechniques to calculate the oconomic 81. See id. (reponing a

value $\$ 1.6$ million retum for manufacturing resource planning

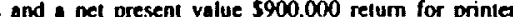
reuse components)

83. Of cource the netums for neumble software writuen for internal reuse would be even greater if the praducer could also uhwin payment for exiemal reuse of components.
} 
However, when the producer and consumer of a reusable component are from different organizations, it is more difficult to produce an integrated accounting of costs and benefits. In such a case, the producer must recover costs (including a reasonable return on investment) directly from external purchasers of his components. Since a user can readily copy and distribute components without payment to the original producer, production incentives boil down to methods for physically, electronically, or legally preventing others from appropriating the benefits of a producer's investment. ${ }^{84}$ In Part III, we consider the efficiency of various software innovation incentives.

\section{Investment in Reusable Software Components}

\section{A. The Public Goods Problem}

The external market for reusable software components exhibits all the features of a classic "public goods" problem. ${ }^{35}$ Public goods have two distinguishing features that are well described in the economic literature. ${ }^{86}$ First. costs of exclusion are high, so that once the good has been provided it is very difficult to prevent those who do not pay for the good from benefitting from it. Second, consumption of the good is "nonrivalrous," meaning additional consumers of the good do not deplete the quantity available to others, so the normal economics of scarcity do not apply.87 Because producers cannot prevent those who do not pay from benefiting from a public good, they will have difficulty collecting payment from consumers. As a result, absent some mechanism for appropriating their value, the private market will tend to undersupply public goods. ${ }^{\circ 8}$ In the software context, because the cost of copying or transmitting software from one person to the next is low, it is difficult to prevent rapid and uncompensated dissemination once the software is created and released. ${ }^{89}$ For this reason, software products in general, whether distributed in object-code

84. See Peter S. Menell, An Analysis of the Scope of Copyright Protection for Application Progrums, 4 I Stan. L. Rev. 1045, 1059-65 (1989) (assessing the need for legal protection for software by analyzing the effoct of contract, anticopying devices, pivet ives for development of public goods).

85. See ROsent CODTER R THOMAS ULEN, LAW AND ECONOMics $108-12$ (1988) (describing the

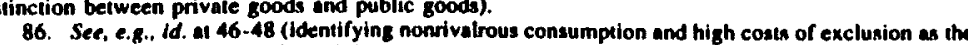
distinguishing characteriatics of a public good).

87. See id.

88. See Paul A. Samuelson \& Willam D. Norohaus, Economics 49 (12th ed. 1985) ("Private provision of these public goods will not occur because the benefits of the goods are dispersed so widely ross the populacion that no single firm or consumer has an incentive to provide them.").

to software

\section{enerally:}

[T/he information comprising innovation in application programs is a prime example of a public good. Given the case and low cost of copying application programs, it is often impossiaveilable. Moreover, one person's use of the information does not decract from others' use of that same information. Since application program creators cannot reap the marginal value of their efforts under these circumstances, they will, in the absence of other incentives, tend to undersupply new and betier application programs.

Menell, supra note 84, at 1059 (citutions omitted). Today, complete software libraries can be transmitled around the globe in a matter of seconds. (computer readable) or source-code (human readable) format, raise substantial public goods issues.

The public goods problem is not unique to the software industry; all developers of intellectual propenty face the same problem. However, a viable market in reusable components must overcome additional barriers to induce a switch from production of traditional software programs. To the extent that reusable components cost more to develop than comparable, nonreusable programs, 90 producers must be able to recoup that additional cost if they are to have any incentive to invest in reusable rather than traditional programs. Further, because selling components in source code form to a potential competitor is riskier than selling a complete program in object code form to end users, ${ }^{91}$ software developers must have some incentive to sell components rather than full programs.

Because reusable components are designed to be transmitted to intermediary developers who incorporate them as building blocks into a wide variety of software systems marketed 10 end users, their risk of appropriation may be higher than the risk for ori inary custom or mass market software. Specifically the risk is greater that a sophisticated software company will incorporate the component into its own integrated program, or alternatively that it will duplicate the component for resale to other integrators. ${ }^{92}$ This is particularly true if the component is given to purchasers in source code as well as object code form. Purchasers who receive the components in source code can adapt the components to make them work well with other components. ${ }^{93}$ Therefore, absent mechanisms that prevent unauthorized users from appropriating the benefits of a software producer's investments, a rational producer will not invest in creating components for external use because he will be unable to recoup his investment.94

90. See notes $74-75$ supra and accompanying text.

91. Most mass market software producers distribute their programs in object code form, which makes it difficult for competitors or subsequent users to resd or modify the progrem. To do so. user must first reverse engineer the object code into some reasonable approximation of source code. This is a difficult and time consuming process. See Andrew Johnson-Laird, Reverse Engineering of Software Separating Legal Mythology Fram Actual Technology. S Sortwane L.J. 33I. 342.43 (1992) ("Idjeciphering compuler-execuinble programm is extremely ledious and error prone"). Programs dis is that the comperitor will mever, can be easily read and modified. The nisk with software compondenis is that the competitor will make unauthonzed use of source code. While it is possible that purchasers than it is to adapt or reverse engineer

92. By contrast, other types of appropriation are more difficult with sofiware components than with integrated systems. It is less likely that purchasers will casually copy the component on a sinall

93. For example, consider programs wrinen in a language like lava script "IS If ware systern embodied either in scripts or in at least some interpreted languege does not have "Separate 'mechine. readable' form. Thus, the developer cannot deliver a completed projoct without revealing the source materials for this type of sofiware." Hank Barry. The Deal Corner. Cranerspace LAW.. May 1996. at
19. 20 .

94. Cf. Janusz A. Ordover. Economic Foundations and Considerations in Provecting Industrial and Inrellectual Properry. 53 Anntrust L.J. $503,505.06$ (1985) (discussing problems of ap- 
To be sure, certain producers may be able to recoup their investment in reusable components wholly through internal reuse. Indeed, factory scale software enterprises such as Microsoft and HP, which have ongoing internal reuse programs, appear to be doing just that. ${ }^{93}$ However, given the dearth of components on the external market, it appears that producers find sales or licensing of components outside the firm unprofitable in the current legal environment. Even producers with large internal reuse programs, for whom the marginal costs of marketing already developed components externally would be small, generally do not sell their components outside the corporation.

Finally, other concerns may make producers hesitant to market software components even after they have been developed. In particular, the potential for tort liability may have a chilling effect on the external reuse market 96 Producers may also believe that sales and licensing will lead to loss of trade secrets or other proprietary information. ${ }^{97}$ However, many reusable components involve no proprietary information of any kind (aside, of course, from the intellectual property in the component itself). For example, a software component which maintains a linked list of generic data structures and manipulates these lists typically contains no proprietary information and is of well-known design. ${ }^{98}$ While a potentially broad external market exists for such a component, programmers routinely code, debug, and test linked list software from scratch. Indeed, one of the authors estimates that he has coded such software from scratch five to ten times during his career as an engineer.

The rest of this article will focus on the incentives for external software reuse. We consider two approaches to enabling producers of reusable software components to recoup their investments: (1) those based on de facto or de jure restrictions on access to the software and (2) those premised on dissemination of the software under protection of the federal intellectual property laws.

\section{B. Access Restrictive Methods for Appropriating Returns}

Conceptually, the simplest way to prevent unauthorized users from appropriating the benefits of a producer's investment in a component is to keep the component secret. Secrecy is relatively easy to achieve for a producer of components for internal reuse, since the source code does not leave the company. By contrast, disseminating components for external reuse creates a risk of appropriation by nonpaying users. Trade secrecy, encryption, and to a lesser ex-

95. See Frakes \& lsode, supra note 22, at 16.

96. See GAO REPOMT ON SOFTWARE ReusE, supra note 19, at 13 (stating that the uncertein exten of software producen' liability for harm altributable to software componenis is a major concerm of nenis which ane used in lifes a large market for standard electronic and mochanical handware compoin is hard to imagine why a simil 97. The fear thet collun software.

the component itself will be copied. The laner problem is disc lost is distinguishable from the fear the nying rext.

98. For - discussion of linked list dein structures, see Merci A. Hemilton \& Theodore M. Sabety. Compurer Sclence Concepts in Copyrighi Cases: The Path to a Coherent Law, II HAnv. J.L. \& TeCi. (forthcoming 1997). tent, first mover advantages each restrict access (either physically, electronically, contractually, or de facto) and therefore potentially limit the risk of appropriation by nonpaying users.

\section{Trade secret protection.}

Unlike patents and copyrights, which are controlled by federal law, trade secrets are governed by the laws of the individual states. Despite this potential for variation among states, modern trade secret law is relatively uniform because its development has been dominated by two major sources, the Restatement of Torts ${ }^{99}$ and the Uniform Trade Secrets Act. ${ }^{100}$ Under the Uniform Act.

"Trade secret" means information, including a ... program ... that ... derives independent economic value, actual or potential, from not being generally known to, and not being readily ascertainable by proper means by, other persons who can obtain economic value from its disclosure or use, and ... is the subject of efforts that are reasonable under the circumstances to maintain its secrecy. 10

The Restatement definition, adopted by courts in a number of states, differs primarily in its requirement that the confidential information be in "continuous use" in the trade secret owner's business. ${ }^{102}$

In either case, it is well established that trade secret law protects the secrets contained in a software program from misappropriation, provided the source code remains secret. 103 Once the information contained in the software be comes common knowledge to those programmers for whom it has economic value, it ceases to be a trade secret. ${ }^{104}$ Therefore, software may not be freely disseminated as source code and still retain its trade secret protection. ${ }^{105}$ In

99. See generally Restatement of Tonts $\$ 8$ 757-58 (1939) (setting forth the basic principles of inde secret law).

100. See Unir. Trade Secrets Act 1 (amended 1985), 14 U.L.A. 438 (1990). Forty stales and the Districl of Columbia have enacted the Uniform Trade Secrets Act in one form or another. See 14 tion in bilateral and multilatenal agreements also encourages trade secret uniformity by obligating the United Sutes to provide a minimum level of trade secreet protoction nationwide. See. e GATT Agree ment on Trude-Related Aspects of Intellectual Property Rights Including Tnde in Counterfeit Goods, 33 1.L.M. 84, 98 (Dec. 15, 1993) (providing for the legal protection of "undisclosed information"); Lino Sys. V. Sangyong Cement Indus. Co.. No. C-89-3832 VRW, 1993 U.S. Dist. LEXIS 12198, at*1-2 . Cal. Aug. 19, 1993) (implying a federal trade secret cause of action under Lanham Act Section 4 parties 1996 U.S App Lex 8445 (Fed obligations 10 South Korean). dismissed by agreement of parteral criminal . App. Lexis 8445 (Fed. Cir. Mar. 26. 1996). Finally, in 1996 Congress passed

102. See Restatement Of Act 1 1(4) (amended 1985). 14 U.L.A. 438 (1990) (emphasis added). formula, pattern. device, or compitation of information which is used in one's business, cond which of any him an opportunity to obuain an advantage over competitors who do not know or use it. simply information as to single or ephemeral events ... but rather a trade socret is a process or device S. Chisum \& Michase. entr Law 3 Cii] (1992).

104. See nole 101 supro and accornpanying lex.

1971) (holding that company which Digital Computer Controls Corp., 297 A.2d 433, 436 (Del. Ch 
order to maintain its trade secret status, access to source code must be re stricted, whether physically, by contract, or by a duty of confidentiality. ${ }^{106}$

Physical control over the code is impractical if producers of reusable components ultimately want to sell (or license) their components to software developers for incorporation in applications and systems. They must reveal their source code to facilitate such incorporation. ${ }^{107}$ Distribution of components in object code format, when viable, ${ }^{108}$ may preserve the secrecy of the underlying source code, particularly if the code is accompanied by enforceable contractua restrictions on reverse engineering and disclosure of the trade secrets contained in the code. In Data General Corp. v. Grumman Systems Support Corp., ${ }^{109}$ the court held that the contents of a computer program distributed only in object code format were protectable trade secrets. ${ }^{110}$

Reverse engineering a publicly distributed product to identify the secrets contained therein does not violate the trade secret laws. "II Instead, it is usually considered proper to use reverse engineering techniques to regenerate source code from the distributed object code. Despite popular misconceptions, however, software reverse engineering methods are time-consuming and labor-intensive. 112 As a result, distribution in object code format, if feasible, does provide the producer with some level of confidence that source code will remain a trade secret.

Trade secret protection does not enable a component producer to fully appropriate the benefits of his investment for three reasons. First, under Date General the authorized distribution of object code does not itself disclose trade secrets contained therein. Unauthorized further distribution of the object code

the program code as a trade secret, where esch of the recipients was in a contractual relationship with vendor), aff 'd. 297 A.2d 437 (Del. 1972).

106. See $1 d$.

107. See note 93 supra. Electronic security via encryption is an altermative to physical security. Some have even suggested that encryption will make intellectual propeny obsolete as a means for defining property rights in cyberspace. However. encryption of a program is only of limited value to vendors able 10 misappropriate the decrypted program. We discuss this issue in more dernil in the pext section 108. Computer programs are typically distributed to customers only as man the nexi section. code, whike human readeble source code is retained by the developer. Stantically linkeble and dynemically linkable libraries are good examples of reusable software components that might be distribunte in object code form.

109. 82S F. Supp. 340 (D. Mass. 1993), aff 'd, 36 F.3d II47 (1st Cir. 1994).

110. See id. at 359 (holding that distribution in object code successfully preserved secrecy, and Therefore inade secret status). Bur see Trandes Corp. v. Guy F. Atkinson C0., 996 F.2d 655, 663 n.8 (4th Cir. 1993) (noting that widely distributing object code destroys trade secrecy of the object cade, even though the secrecy of the source code may remain intact).

111. According to the Uniform Trade Secrets Acl, proper means includes:

(d)iscovery by "reverse engineering". (sic) that is, by starting with the known product and working backwand to find the method by which it was developed. The acquisition of the known product must, of course, also be by a fair and honest means, such as purchase of the item on the open market for reverse engineering to be hawful.

UNIP. TRADE SECRETS ACT 1 CmL. (amended 1985). 14 U.L.A. 438 (1990)

112. See Johnson-Laird, supra note 91, it 343 (explaining that reverse enginoering techniques require up to a minute to decipher a single compuler instruction and that \& typical program may contain ers are free to decompile a product contuining a software innovation but decompilation is difficult and time-consuming). by others therefore does not "misappropriate" those trade secrets, which remain undisclosed. 113 To protect the object code itself against further copying and distribution, the component producer must either rely on the federal copyright laws or create separate contractual restrictions on dissemination. 114

Second, because programmers must integrate many components into a larger system, distribution of only the object code of a component may not be a feasible altemative. Unlike complete software systems, where the purchaser is generally an end user who simply wants the program to work, many software components must come with "assembly instructions" to be fully useable. As a general matter, this means that some source code will have to be distributed along with the component.

Finally, disclosure of a trade secret to the public-for example by placing it on the Internet - forever destroys the secrecy of the program. 11s Thus, widespread distribution of a computer program under an assumption of secrecy is fragile protection indeed. One significant act of misappropriation can destroy the secret by exposing it to the entire consuming public. While the trade secret owner will likely have a cause of action against the person who discloses the program, that fact may provide small solace for the loss of the secret itself.

\section{Encryprion. 116}

Of late, two very popular topics of discussion in cerain circles on the Internet have been encryption technology and the undesirability of using patent and copyright law to cover software and digital works. Some have even synthesized the two, suggesting that encryption, or "crypto-bottling," replace patent and copyright as the means for defining intellectual propeny rights in cyberspace. ${ }^{117}$ We argue that while cryplography is extremely useful in estab-

113. Under the Uniform Trade Secrets Act, "misappropriation" is defined as:

acquisition of a trade secret of : Sother by a person who knows or hes reason to know that the trade secret was acquired by improper means; or ... disclosure or use of a inade socret of enother without express or implied consent by a person who ... used improper means 10

acquire knowlodge of the trinde secret.

Unif. Trade. SECrets Act 1 1(2) (amended 1985). 14 U.L.A. 438 (1990) (emphasis added). " 'Improper means' includes theft, bribery. misrepresentation, breach or inducement of a dury to maintain secrecy, or espionage through electronic or other means." Id. I(1). 14 U.L. A. 437; see Trandes Corp. 996 F.2d in 660 ("The significant difference of fact berween trade socrets and processes or devices which are nor secret is that knowledge of the later is available to the copier withoul the use of improper 列

114. For an example of the latter npproach, see ProCD, Inc. v. Zeidenberg. 86 F.3d 1447 (7th Cit. shrintwnp license). For further discussion of contract protoction, see note 279 infra end accose with 1

115. See, e.g. Religious Technology Cur. v. Lerma, 908 F. Supp. 1362. 1368 (E D. V. 1995) "Once s trade socret is posted on the Internet, it is effoctively part of the public domain, impossible to retrieve.").

116. Encryption is a process whereby data, including software programs. are encoded so as to be unreadable without the oppropriate decoding key. See A. Michael Froomkin, The Melaphor is the Key: Cryptography, the Clipper Chip. and the Constitution, 143 U. PA. L. REv. 709. 718.64 (1995)

117 . See. e.g. John P. Barlow, The Economy of Ideas: A Framework for Reshinking Patents and Copyrights in the Digiral Age (Everything You Know About Intellectual Property Is Wrong). WiRed. 
lishing security barriers to unauthorized access, it is not a new paradigm destined to supplant intellectual property law. Rather, it simply establishes more effective barriers to reverse engineering (decryption) than does embedding a program in object code. Even assuming that it provided perfect security, which it does not, encryption merely shifts the focus of trade secret misappropriation to the end user. Software components must be decrypted to be valuable to purchasers and end users of an integrated software system. While encryption better protects against unauthorized access to the component, it can not preven unauthorized use or disclosure of the encrypted ideas by those who have legitimately acquired and decrypted them.

\section{First mover advantages.}

Innovators who are first to market often enjoy substantial advantages over later imitators even when access is not physically, electronically, or legally restricted. ${ }^{18}$ This first mover advantage is not premised on any direct effort to restrict access to proprietary information; it results from practical limitations on access and delays associated with incomplete knowledge. Empirical data shows that such first mover advantages function as innovation incentives. For example, one study of large corporations in various industries concluded that head start advantages, including the establishment of production and distribution facilities, was more effective than the use of patents in enabling firms to reap returns from innovation. 19 In fact, Nancy Dorfman argues that first mover advantage has been the primary reason for innovation in the computer and semiconductor industries. 120

The first mover advantage is not as great a factor in the production of software components for external reuse markets as it is in the software industry more generally. The magnitude of first mover advantages in an industry is directly related to the cost of transmitting an innovation to others. ${ }^{121}$ Low transmission costs allow first mover advantages to dissipate quickly, while high transmission costs allow a first innovator to appropriate much of the value of his innovation.122 Software copying, particularly exact duplication of object Mar. 1994, as 84. 129 (suggesting that "Crypto Bottling" will replace patent and copyright as a means of
intellecturi property prolection in the digitul oge); David Friedman. A World of Strong Privacy: Promises and Perlis of Encrypsion. 13 Soc. PHn. \& Poi' Y 212. 220 (1996)

118. Strictly speaking, this is not an "eccess-restrictive" method of appropriating returns. We have placed the first mover edvantage in this caregory, however, because it depends on competitors" inubitity to discover and duplicate an innovation in a short period of time.

119. Richord C. Levin. Alvin K. Klevorick, Richard R. Nelson \& Sidney G. Winter, Appropriating the Returns from Indusfrial Research and Development. 1987 BnOokinOs PAPERs on ECON. Acriv irr 783, 815-16 (concluding that the patent system and related institutions "improve the approprisbility of returns from innovation." but "are not the only nor nocessarily the primary barriers that prevent Innovation: An Empirical Study. 32 Momr. Scr. 173, 176 (1986) (examining the extent to which various firms and industries rely on the patent system to protoct their innovations).
120 . See NANCr S. Donnman, InNovation AND MARker Stmucture: Lessons MTRE AND SEMKCONDUCTOR INDUSTRIES 235-39 (1987).

121. See Ondover, supra note 94, it 505.06 (discussing the effoct of transmission costs on appropriability).
122 . See id.

code, is quick and easy. The first mover advantage is therefore probably less significant in the software industry than in the stable industries in which survey data has typically been gathered.

A related problem in markets characterized by rapid technological change is the ability of an imitator to incorporate a rival's innovations into its own leapfrogging innovations. ${ }^{123}$ 'ihe software industry is made up of a small number of dominant firms, such as Microsoft and IBM-Lotus, and a large number of comparatively small firms. ${ }^{124}$ This market structure places dominant firms, with their large development, marketing. and distribution resources, in a strong position to imitate and capitalize at a worldwide level on the innovations of their smaller rivals. ${ }^{125}$

Further, a market for commodity-type software components is likely to develop around the attributes of durability and reliability. These attributes require repeated use and testing of the component over time. Copying of a successful component can prevent its developer from recouping additional money invested in such long-term attributes. Thus, an external market for reuse is even more vulnerable to rapid imitation than the traditional software market.

From a software reuse perspective, the first mover advantage appears to create incentives for internal software reuse. Organizations striving to be first to market will attempt to build on proven software implementations, rather than incur the delays and risks associated with developing code from scratch. The development of extensive internal reuse programs at AT\&T, Digital, HP. IBM, Microsoft, and Motorola supports this conclusion. ${ }^{126}$ It is less likely, however, that first mover advantages will result in significant dissemination of software components in the external reuse market; indeed, it is likely that producers perceiving an opportunity to exploit first mover advantages will develop software components for internal reuse and attempt to protect those components as trade secrets. By encouraging a short-run focus, first mover advantage, like trade secret and encryption, may encourage the climate of reinvention.

4. Disadvantages of access restrictive approaches.

A principal drawback associated with trade secret, encryption, and first mover advantages is the high risk that these access restrictions will fail. Trade secrecy may be lost through reverse engineering or unlawful dissemination by a

123. See Joseph Kartan, Antirust Analysis of Technology Joint Ventures: Allocative Efficiency
and the Rewards of and the Rewards of Innovation. 61 ANrrtnust L.J. 937. 942.43 \& $\mathrm{n.32}$ (1993) ("imitators can incorporate rivals' innovations in their own innovations that leapfrog the originators' technological advantage").

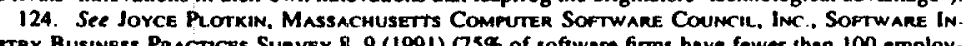
Dustra Business Practices Surver 8. 9 (1991) (75\% of sofiware fims heve fewer than 100 employ-

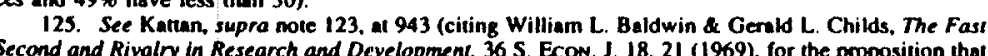
first mover advantage may not necessurily hold for markets in which dominant firms are well situated to enter quickly with imitations of smaller rivals' innovations)

126. See Lim. supra note 27, at 26 (noting time to market advanugges associated with sofmare reuse); Frakes \& isoda. supra note 22, at 15-16 (listing companies that have implemented software reuse programs to gain competitive advantage). 
judgment-proof defendant. Even if a solvent defendant can be identified, proving loss from dissemination of a secret on the Internet to recover consequential damages may be a daunting task. Encryption algorithms may be "cracked,"I27 or a program may be disseminated after authorized decryption. First mover advantages may be unsustainable and can be lost through reverse engineering. In each of these cases, once disclosed, the secret cannot be retrieved from the public domain.

Access-restrictive approaches are also problematic from a social perspective because they disfavor dissemination of technical ideas. Progress in computer science, the useful arts, and programming, as in other fields, depends on the ability of innovators and researchers to build up on earlier advances. Sir Issac Newton made this observation in a letter to a friend: "If I have seen further it is by standing on ye sholders of Giants."128 Unlike copyright and patent law, which encourage dissemination 129 and contain mechanisms for separating out portions of the disseminated material as unprotected, ${ }^{130}$ access restrictive approaches encourage secrecy. Dissemination is antithetical to the goals of trade secret law and encryption. Finally, secrecy is largely incapable of differentiating between that which must be protected to ensure that the component developer retains control of his innovation and that which need not be. Thus, it may encourage too much secrecy. ${ }^{131}$

\section{Exclusive Rights Under the Federal Intellectual Property Laws}

Intellectual property protection presents an alternative method of solving the public goods problem presented by reusable software components. By providing a limited opportunity for exclusive control over products, intellectual property protection enhances the expected reward to those who create protected works. ${ }^{132}$ At the same time, the law requires public disclosure and registration. This economic incentive fosters a climate of innovation and product develop-

\footnotetext{
127. See Steven Levy, Wisecrackers, Wined, Mar. 1996, \&1 128, 128 (suggesting that encryption gorithms are more vulnerable to altack than previously supposed).

128. Robert K. Merton, On twe Shoulders on Giants: A Shandean Postscaim 31 (1965) (quoling Feb. S, 1675/1676 letter from Sir Isanc Newton to Robert Hooke); see Lorus Dev. Corp. Paperback Sofiware Int'1, 740 F. Supp. 37. 77 \& n.3 (D. Mass. 1990) (commenting on the "on the 129. Cop giants" principle in relation to software).

129. Copyright hw encourages dissemination through publication. See Rober A. Kreiss, Accessiblliry and Commercialization in Copyright Theory, 13 UCLA L. Rev. 1. 4-5 (1995). Patent Law requires disclosure by the inventor to the public sufficient to enable one skilled in the art to which it pertains to

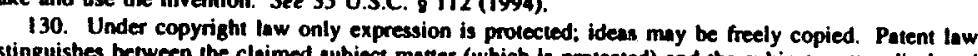
but not claimed (which is domated to the public (which is protected) and the subject matter disclosed $1106-08$ (Fed. Cir. 1996) (holding that matrer disclosed in a perent but not cheser. Inc.. 86 F.3d 1098 public).

13I. See Edmund W. Kitch, The Law and Economics of Righis in Valwable Information, $9 \mathrm{~J}$ LeOAL STud. 683 (1980).

132. See Menell, supra note 84, at 1059. ("Enhancing the scope of intellectual property protoction

(by increasing the duration or breadith of production) increases the expected reward to thoso engesed in iniellectual work by enhencing the opportunity for monopolistic exploitation of any products creared.")
}

ment. ${ }^{133}$ Patent and copyright law are the principal sources of intellectual property rewards for software, although trade secret law may also play an important role. ${ }^{134}$

\section{Copyright law.}

Copyright subsists in "original works of authorship," including computer software, which are "fixed in any tangible medium of expression."135 Copyright protection arises automatically upon fixation of the work on paper, magnetic tape, magnetic disk, semiconductor chip or any other permanent medium. The work must be original to the author, ${ }^{136}$ but copyright protection does not require that a work be novel or that it be a substantial change from what was done before. ${ }^{137}$ Moreover, copyright, unlike patent, does not require government examination or approval. The owner of a copyrighted work has the exclusive right to reproduce the work and to prepare derivative works therefrom (or authorize others to do the same). 138

Because patent and trade secret law have traditionally been associated with utilitarian works, the historical view of copyright law as the proper means of protecting computer software is somewhat surprising. Copyright law protects only the expression of a particular idea, not the idea itself. ${ }^{139}$ The Copyright Act specifically excludes frorn protection "any idea, procedure, process, system, method of operation, concept, principle, or discovery."100 The scope of copyright protection for software has ebbed and flowed over the years. In its report on software reuse, the General Accounting Office cited the uncertain scope of copyright protection for software components as a major impediment to cooperation among suppliers, repositories, and users of reusable software components. ${ }^{141}$

Software copyright infringement law has developed over several generations of cases, each redefining the scope of copyright protection for elements of program code. ${ }^{142}$ The first generation of cases established that direct copying

133. See id. ("These increased rewands encourage inventive activity, which in fum spurs the discovery of new and betier products."): see also Lovis $\mathrm{K}$ praisal. 97 Hanv. L. Rev. 1813. 1823-24 (1984).

134. See notes $99-115$ supra end accompanying lext (discussing trade secret law).

135. 17 U.S.C. $102(1)$ (1994)

136. See Feist Publications, Inc. y. Rural Tel. Serv. Co., 499 U.S. 340, 437.49 (1991) (mandating originality as a prerequisite for copyright protection).

137. See Chisum \& Jacoss. supra note 103. 1 18[3]

138. See 17 U.S.C. $106(1)$-(2) (1994)

139. See Mazer v. Stein, 39 Y U.S. 201.217 (1954) (construing Baker v. Selden, 101 U.S. 99 (1879)): 1 Melville B. Nimmen \& David Nimmer. Nimmer on Copyright (1996) 8 2.03|D], at 2.34

140. 17 U.S.C. $102($ b) (1994)

141. See GAO Reront on Sortwane Reuse. supra note 19. a 12-13 ("IA] major challenge facing sofiware reuse is to balance these fintelloctual properiy) rights between sofiware suppliers, reposito-

142. For a more delallod discusslon of this historical development, see Mark A. Lemley, Conversence in the Law of Software Copyrigh?? 10 HiGH TECH. L.J. I (1995). 
of the precise coding of computer software constituted infringement. ${ }^{143}$ Under this line of cases, copyright protection extended to only an innovator's specific implementation of a software component in code. The innovator could prohibit others from directly copying that code, but not from duplicating organization or programming techniques.

Whelan Associates v. Jaslow Dental Laboratories ${ }^{144}$ ushered in a second generation of cases in which courts began to protect application program code on the basis of nonliteral infringement - the duplication of a program's organization without the literal copying of any significant portions of the code. 145 The Whelan court adopted an expansive definition of expression within the structure, sequence, and organization of a computer program. ${ }^{146}$ The court reasoned that "everything that is not necessary to the purpose or function [of a utilitarian work] would be part of the [protectable] expression."147 This broad scope of protection conflicted with the Copyright Act's express prohibition of copyright for ideas, procedures, processes, systems, methods of operation, concepts, principles, and discoveries, ${ }^{148}$ and most commentators criticized Whelan's extension of copyright scope as inconsistent with the statute. ${ }^{149}$

More recently, in the third generation of software copyright cases, courts have refused to apply the Whelan standard. Led by Computer Associates International v. Altai, Inc. ${ }^{130}$ in 1992, these courts have advanced a much narrower "abstraction-filtration-comparison" test to determine whether two programs are substantially similar. ${ }^{151}$ The Allai analysis limits the scope of copyright protection of nonliteral expression by requiring that elements of the program that are dictated by efficiency or external factors and elements taken from the public

143. See, e.g. Apple Computer. Inc. v. Franklin Computer Corp., 714 F.2d 1240. 1253 (3d Cir. 1983); Williams Elec., Inc. v. Antic Int'I. Inc., 685 F.2d 870 , 877 (3d Cir. 1982). Unauthorized, direcl copying of computer code, in whole or in pert, constitutes literal infringement of the copyright holder's exclusive rights to reproduce the copyrighted work and to prepare derivative works based on the copy144. 797 F. 2 d 1222 U.C. 106 (1988).

144. 797 F.2d 1222 (3d Cir. 1986). grams" literal code to their sinucture, sequence, and computer prograr

146. See lecte their structure, sequence, and orgenization"). 146. See Lemley, supra note 142, at 10-12; Menell, supra note 84, at 1074 (examining the Whelan

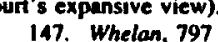

147. Whelan, 797 F.2d al 1236.

149. See, e.g. 3 Nimmer \& Nimmen, supra note 139, 13.03 [A||l]|d], at 13-45 to -48; Menell,

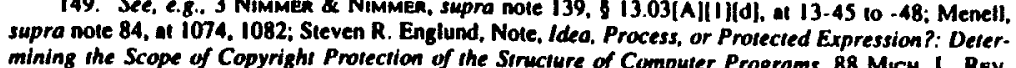

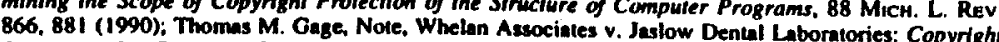
Protection for Compuler Software Siructure - What's the Purpose?, 1987 Wis. L. Rev. 859, 860-61. 881, 884, 891-93: Mart T. Kretschmer. Note, Copyrighs Protection for Software Archilecture: Just Say No!, 1988 Colum. Bus. L. Rev. 823, 837-39; Peter G. Spivack, Comment, Does Form Follow Function?: The Idea/Expression Dichotomy in Copyright Protection of Computer Soffware, 35 UCLA L. Rev. 723, 747-55 (1988): of. Pamell Samuelson. CONTU Revisited: The Case Against Copyright Pro. rection for Compuler Programs in Machine Readable Form, 1984 DUxE L.J. 663, 732-36 (arguing that 150. 982 Fot protect computer programs).

150. 982 F.2d 693 (2d Cir. 1992).

computor programu rolica 100 heovily on methelan's approach to separating idea from expression in on prectical consideretiona.").

domain be filtered out. 132 Virtually all courts issuing opinions in software copyright cases since 1992 have followed Altai. ${ }^{153}$ However, while courts agree on using the Altai test, they do not always agree on how to apply that test. ${ }^{154}$

Courts and litigators also disagree about whether copyright law prevents reverse engineering by a competitor in order to develop compatible systems. One early case held that a user could not justify copying a copyrighted program in order to achieve compatibility with that program. 135 More recently, however, courts have been uniformly receptive to arguments that copying certain portions of copyrighted programs is justified either to reverse engineer the program or to build interoperable programs. ${ }^{156}$

A final set of disagreements over software copyright law came to the fore in 1995. when the First Circuit reversed a series of related lower court decisions concerning the menu command structure of the Lotus 1-2-3 spreadsheet program. ${ }^{157}$ The First Circuit declined to follow Altai's abstraction-filtration-comparison test, instead holding that the Lotus 1-2-3 menu command hierarchy is an entirely unprotectable "method of operation" under 17 U.S.C. $102(\mathrm{~b}) .158$ The majority did not treat the case as an issue of compatibility between programs, as Judge Boudin ..dvocated in his concurrence. ${ }^{159}$ This decision placed the First Circuit at odds with several other circuits that had read the "method of operation" language more narrowly. 160 While the Supreme Court granted certi-

152. See id. at 707-10

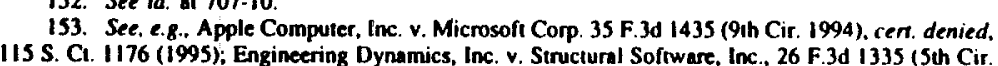
1994); Gates Rubber Co. v. Bando Chemical Indus., 9 F.3d 823 (10th Cir. 1993). For a complete list. see Lemley, supra note 142, at 15.

154. See Lemley, supra note 142, at 21-25 (discussing areas of confusion that remain in applying

the Aleail lest).
155. See Apple Compuler. Inc. v. Franklin Compuler Corp., 714 F.2d 1240, 1253 (3d Cir. 1983); see also Digital Communications Assoc. v. Sofiklone Distrib. Corp. 659 F. Supp. 449. 462.63 (N.D) Ga. 1987); Anthony L. Clapes, Conjessions of an Amicus Curiae: Techrophobia. Law and Creativiry in the Digiral Ars. 19 U. Dartow L. Rev. 903 (1994); Arthur R. Miller. Copyright Protection for Com. puter Programs. Databases, and Compuler-Generated Works: Is Anything New Since CONTU?, 106 - copyrighi exception for reverse engineering). 156. See. e.g., DSC Communications v. DGI Tech., 81 F.3d 597. 601 (5th Cir. 1996); Baleman v.
15yright excepion for reverse enirering) Mnemonics. Inc., 79 F.3d 1532 . 1539 n.18 (11th Cir. 1996): Lotus Dev. Corp. v. Borland Int '1, Inc., 49 Accolsde, inc., 977 F.2d $1510,1527-28$ (9th Cir. 1992). aff d, $116 \mathrm{~S}$. Cl. 804 (1996). Sege Enter. v. 975 F.2d 832. 843-44 (Fed. Cir. 1992); Vauli Corp. v. Quenid Soltware Lid., 847 F.2d 255. 270 (Sth Cir. 1988): Mitel Inc. v. Iqtel Inc. 896 F. Supp. 1050 (D. Colo. 1995); Jomathan Band \& Masanogu

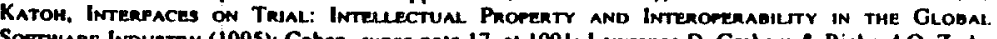
SOFTwake Industre (1995); Cohen, supra note 17, at I091; Lowrence D. Grahem \& Richard O. Zerbe Ir., Economically Efficient Treatment of Computer Sofwware: Reverse Engineering, Protection, and Dis. closure. 22 Rutaers Compurten \& Tech. L.J. 61 (1996); Dennis S. Karjala. Copyright Protection of (1994): David A. Rice, Sega and Beyand: A Beacon for Fair Use Analysis . A Leass as Far as it Goes, 19 U DArmon L REv 1131,1168 (1994).

is7. See Lorus Dev. Corp. 49 F 34 (1994).

158. See id. a 815 .

159. See Id. al 821 (Boudin. J., concurring).

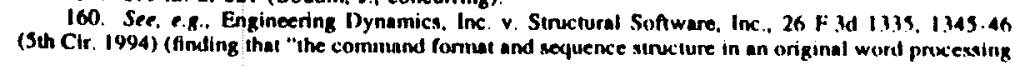


orari to resolve the split in the circuit opinions, one week after oral argument the Court issued an affirmance without opinion. ${ }^{161}$

In short, in each of the three main computer software copyright issues, the courts have cut back the scope of protection rather dramatically in the last five years.

\section{Patent law.}

This limitation of software copyright has coincided with a trend towards using patent law to provide protection for software. Section 101 of the Patent Act defines patentable subject matter as "any new and useful process, machine, manufacture, or composition of matter."162 To qualify for a patent, an invention must meet the requirements of utility, novelty, and nonobviousness. ${ }^{163}$ Unlike copyright, which arises automatically, a patent may be obtained only by filing an application in the PTO. ${ }^{164}$ The application must describe both the subject matter of the invention and the metes and bounds of the invention claimed 165 Only if the PTO determines thet and bounds of the invention claimed. Only if the PTO determines that the claimed invention is novel and nonobvious will it issue a patent. ${ }^{166}$ An issued patent gives the patent owner the right to prevent others from "making. using, or selling" the product or process claimed by the patent in the United States. ${ }^{167}$ Unlike copyright infringement, independent creation is no defense to a claim of patent infringement

It is a fundamental proposition of patent law that any new and useful process, machine, manufacture, or composition of matter, or any new and usefu improvement thereof, may be patented if it meets the requirements set forth in the statute. 168 However, the courts have held the requirements set forth in the statute. ${ }^{168}$ However, the courts have held that the discovery of a law of nature, an abstract idea or principle, or mathematical relationships, operations, or functions cannot be patented. ${ }^{169}$ Historically, the PTO viewed software components as mere mathematical formulations existing independently of func-

or compuler spreadsheet should be copyrightable because as a whole, the interface's structure and hier-

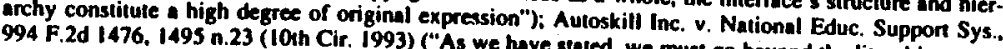

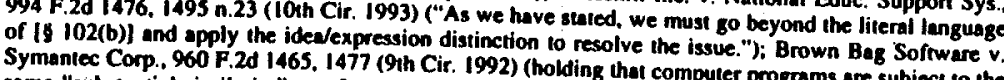

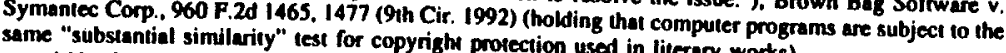
161. Lotus Dev. Corp. yest for copyrigh protection used in literary works).

Courr. 49 F.3d 807 (19t Cir. 1995). 162. 35 U.S.C. $101(1994)$

163. See Chisum \& Jacoss, supra note 103, \& $\$ 1$ 18II]

164. See id.

165. See id.

166. See id.

167. 35 U.S.C. $271(a)(1994)$

168. See in re Alappat, 33 F.3d 1526, 1542 (Fed. Cir. 1994). The court went on 10 say.

The use of the expansive term "any" in 101 represents Congress's intent not to place sny:

recited in 101 and the matter for which a patent may be obuined beyond those specifically

that Congress intended other parts of Title 35. Indeed, the Supreme Coun has acknowledgod 1d. at 1542 (quoting Diamond v. Chakrabarty, 447 U.S. 303,309 " (19 sun that is made by man.

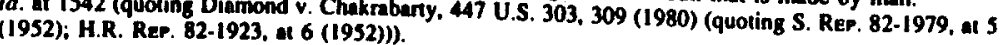

169. See Diemond v Diectr 450 U.

the abstract] is not accordid the protection of our palent laws"). tional stnuctures or processes, and thus refused to extend patent protection to such components. Similarly, in the 1980 s, courts and the PTO regularly rejected patent claims directed to software uniess the claim included an accompanying physical structure. ${ }^{170}$

Since software components are in essence software application building blocks that are independent of physical structure, patent protection has historically been unavailable for them. ${ }^{11}$ More recent opinions of the Court of Appeals for the Federal Circuit raise the possibility that software per se will be patentable subject matter. ${ }^{172}$ These opinions, as well as patent attorneys' skill in characterizing software patent claims as possessing physical structure. prompted a flood of software patents in recent years. ${ }^{173}$

Nonetheless, courts since Alappat have not clearly determined whether certain types of sofiware components, notably data structures, are now eligible for patent protection. In In re Lowry, the Federal Circuit held that an electronic memory with an internal data structure is patentable subject matter even though the requisite novelty resides in the organization of the data structure. 174 The court reasoned that the organization of data objects in Lowry's invention constituted a form of "electronic structure" which served as the basis for patentability. ${ }^{175}$ Lowry is important for software components because the "electronic structure" rationale may apply equally to the organization of data structures and relations among instructions, code modules, and objects. ${ }^{176}$ However, it is not

170. The two-pan test used by cours in the 1980s for analyzing mathematical algorithm cases was set oul in In re Freeman. 573 F.2d 1237 (C.C.P.A. 1978), and modified by In re Walter. 618 F.2d 758 (C.C.P.A. 1980):

First, the claim is analyzed to determine whether a mathematical algorithm is direclly or indi-

rocily recited. Next, if a mathematical algorithm is found, the claim as a whote is funther

analyzed to determine whether the algorithm is "applied in any manner to physical elements or

process steps," and, if it is, it "panses muster under $\$ 101$."

In re Pardo. 684 F.2d 912. 915 (C.C.P.A. 1982) (quoring in re Hislter. 618 F.2d a 767). Under the second port of the cour's test, the claims may be considered without the algonithm to determine whether the remainder is otherwise statulory. See in re Abele. 684 F.2d 902. 907 (C.C.P.A. 1982) ("II) the

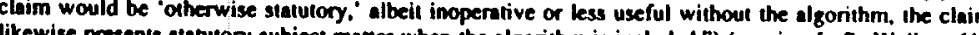
F. 2d at 767).

171. See Parker v. Flook, 417 U.S. 584 (1978) (holding unpalentuble sofwware for serting alurm limits); Gollschalk v. Benson. 409 U.S. 63 (1972) (holding unpatenuble sofwware for converting binary 172. bee Alappar, 33 Fimal numeralss.

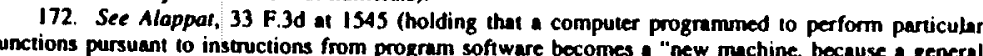
purpose computer in effeci becomes proecial purpose cocomes." new muchine. because a gener

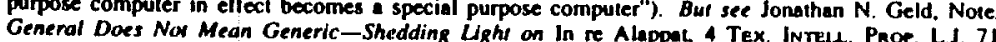
(1995) (orguing that the Alappat court maintained that struclure is neccessery 10 support sof ware patents protection to all software implemented on a generel purpose computer) 173. By the end of 1994, there were approximutely 14,000 United Sintes patenis in existence the covered software. See Sieve G. Sieinberg. Growth of U.S. Soffware Patents, Wined, Jan. 1995, at 54

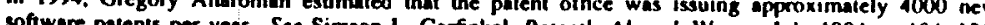

174. See in re Lear. See Simson L. Garinkel. Polenlly Absurd, Wh

174. See In re Lowry, 32 F 3d 1579, 1584.85 (Fed. Cir. 1994).

175. Id. at 1583

12 Coururee Stepten C. Durant, Patents in Cyberspace: Impact of Recent Federal Circuit Decisions, ing whethet courts will interpret instructions, code moduks. and objects as sufficiently structural). 
clear whether other Federal Circuit panels agree with Lowry's holding. For example, in In re Warmerdam the court affirmed the rejection of claims directed to data structures, describing the structures as "nothing more than the manipulation of basic mathematical constructs, the paradigmatic "abstract idea." "In7 The Warmerdam court came to its decision because it found that the software aspect of the patent claim lacked physicality, thus apparently rejecting the "electronic structure" approach. 178

The most recent developments in this ongoing debate are the In re Beauregard 179 appeal and the PTO's issuance of proposed 180 and final 181 guidelines for examining computer related inventions. In Beauregard, the Board of Patent Appeals and Interferences rejected a claim covering software on a floppy disk. While the case was pending on appeal to the Federal Circuit, the PTO declared that it no longer objected to the claim as nonpatentable, and that it would shortly issue guidelines to that effect. 182 The PTO published a Request for Comments on Proposed Examination Guidelines for Computer-Implemented Inventions ("Proposed Guidelines") on June 2, 1995,183 and issued a detailed legal analysis supporting the claims in October 1995, which significantly altered the original guidelines. ${ }^{184}$ This legal analysis was subsequently supplanted by the Examination Guidelines for Computer-Related Inventions ("Revised Guidelines"), published February 28, 1996.185

The Revised Guidelines take the position that data structures which are not embodied in computer readable media and computer programs claimed as mere descriptions of the programs are not physical "things" nor patentable processes. Thus, such data structures and computer programs "do not define any structura and functional interrelationships between [themselves] and other claimed as pects of the invention which permit [their] functionality to be realized."186 By contrast, the Revised Guidelines suggest that a computer readable medium encoded with a data structure or computer program is patentable because it "defines structural and functional interrelationships between the computer program [or data structure] and the medium which permit [their] functionality to be real-

177. In re Wamendam, 33 F.3d 1354. 1360 (Fod. Cir. 1994). The Warmerdan coun did, how-

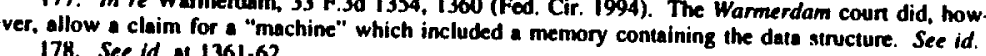
179. 53 F.3d 1583 (Fed.

180. Request for Comments on Proposed Examination Guidelines for Computer-Implemented Inventions. 60 Fed. Reg. 28,778 (proposed June 2. 1995) (hereinufier Proposed Guidelines]. 181. Examination Guidelines for Computer-Reloted Inventions, 61 Fed. Reg 7478 (1996) (heres fter Revised Guidelines].

182. See Soffware Embrodied on Disketre is Parentable Subject Master, PTO Dectares, so Pat. Trademsirk. \& Copyright J. (BNA) 3 (May 4. 1995).

183. See Proposed Guidelines, supra note 180, at 28,778.

mont Proposed Examination Guidelines for Com. Dep't oo Commence, Leonl Analysis to Sup. with the Stanford Law Review). 185. See Revised Guidelines,

lines are final and replace the Proposed Guide 181. at 7478. According to the PTO. the Revised Guide. However, because the Revised Guidelines do nol constiture substantive nulemating See id. al $7487 \mathrm{n}$.I. have the force and effect of law. "any failure of Office personnel to follow the iRevisedt Guidery do no: nable." Id. at 7479 . 186. Id. al 7481-82 ized."187 The formalism of this distinction should make clear that artful drafting by patent lawyers (emphasizing the physicality of the data structure or computer program) may turn supposedly "nonstatutory" computer programs into patentable subject matter.

The Revised Guidelines, in an attempt to char a course between what is and what is not patentable, introduce the concepts of "functional" and "nonfunctional" descriptive material. According to the PTO, " "functional descriptive material' consists of data structures and computer programs which impart functionality when encoded on a computer-readable medium." "Is8 "Non-functional descriptive material," on the other hand, "includes but is not limited to music, literary works and a compilation or mere arrangement of data."189 Descriptive material is not patentable when claimed for itself; ${ }^{190}$ it is patentable when claimed in a way that "structurally and functionally interrelate[s]" the descriptive material to other claimed aspects of the invention. 191

The PTO reasons, somewhat persuasively, that nonfunctional descriptive material, even when encoded on a computer readable medium, defines no structural or functional interrelationships. For example, music does not become patentable merely because it is recorded on a computer readable medium such as a compact disc. As the PTO points out, "[s]uch a result would exalt form over substance." 192 Yet in the context of functional descriptive material, the PTO is prepared to do just that. The PTO explains that "[d]ata structures not claimed as embodied in computer-readable media are descriptive material per se and are not statutory because they are neither physical 'things' nor statutory processes," 193 but adds that "[w] data structure] is recorded on [a] computer-readable medium it becomes structurally and functionally interrelated to the medium and will be statutory in most cases." 194 Since any sofiware program will likely be recorded on some com puter readable medium, it is not clear how much this distinction will accomplish in practice.

The reasoning of the Revised Guidelines tracks the inconsistent contours of Warmerdam and Lowry. Additionally, the PTO's analysis advances "structural and functional interrelationships" between a data structure or computer program and other claimed asperts of an invention as a useful rubric for discriminating among patentable and nonpatentable subject matter. However, analytical reliance on a mere necitation of encoded computer readable media. even in the context of "functional descriptive material," may result in a subject matter inquiry which is both over- and underinclusive. Perhaps as the surrounding jurisprudence develops, both the PTO and the courts will continue to

187. Id. at 7482 . The PTO's choice of the vert "consists" in describing functonal descriprive
188. Id. ot 7481 . The 189. 189. Id.
190. See

191. Id.
191.

192. Id

193. Id

194. Id 
recognize that it is these structural and functional interrelationships, whether between other aspects of an invention (i.e., with tangible, physical media or computer structures) or within the programs or data structures themselves, which distinguish patentable computer related subject matter from nonpatentable abstract ideas. Certainly, many patents issued by the PTO already reflect these structural and functional interrelationships among software components. ${ }^{195}$

In short, there is good reason to believe that the PTO and the courts will allow patents on software components in many circumstances. 196 Further, it appears that other countries may be following suit. ${ }^{197}$ However, greater confusion surrounds the details of exactly which software-implemented inventions are patentable, and exactly what their inventors must claim to comply with the PTO's guidelines for patentable subject matter. This confusion is particularly evident in the area of reusable software components, both because of the Lowry-Warmerdam disagreement ${ }^{198}$ and because under the Revised Guidelines patentability appears to turn on the relationship between a software object and its physical implementation in a particular case. ${ }^{199}$

\section{Intellectual Property Rights and the Future of Soptwarb} Component Transactions

Currently, no viable external market exists for software components. The reasons for this are both technical and economic. On the technical side, a viable market requires some means of evaluating products and transacting business. Several government projects, including NIST's software components program 200 and the Defense Advanced Research Projects Agency's ("DARPA") Asset Source for Software Engineering Technology ("ASSET") national software repository, ${ }^{201}$ have been established to deal with this problem. For example, the ASSET system, which went online in August of 1994 . plans to develop an electronic marketplace for reusable software products by providing an Internet accessible software reuse library for software developers 195. See, e.g. United Sintes Patent No. 5,414,701 (entitled Method and Dath Structure for Per-
forming Address Compression in an Asynchronous Transfer Mode (ATM) System) (discloaing structure consisting entirely of software components); United Sules Patent No. 3,386,375 (entiled Floating Point Datu Processor and a Method for Performing a Fronting Point Square Root Operation Within the Dale Processor) (claiming a method for executing a square root operation).

196. See generally Keith Siephens \& John P. Surme, Patenting Soffiware Objects and Other Aspects of Object. Onented Programs Under the New PTO Guldelines, 23 AIPLA Q.J. 221 (1995) (er

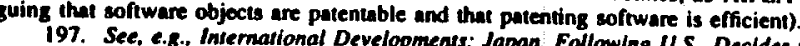

Memory Devices, BNA's . Etional Developments: Japan, Following U.S. Decldes to Allow Pavenis for Office has decided to allow patenting of CD-ROMg. Rer. 466 (Aug. 16. 1996) ("It the Japen Palen proprietary sofiware").

198. See notes $176-178$ supra and accompanying lext.

199. See Revised Guidelines, supra note 181, at 7483, 7492.

200. See Stitch Ups: Soffware, supra note 3, it 99 (reporting the first awands, 10 taling 540 million. 201. See Frakes \& lsoda, supna nose 22 at 16 ("The foderal sover industry).

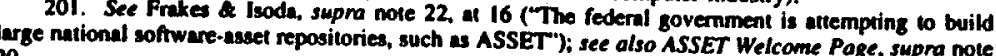

in government, industry, and education. ${ }^{202}$ Other private repositories have developed similar projects. ${ }^{203}$

While these projects address many important technical issues, such as the development of architectures, semantics, and formal languages, ${ }^{204}$ as well as practical issues such as design and implementation of interoperable reuse libraries for storage and retrieval of software artifacts, ${ }^{205}$ they only minimally enhance producers' incentives to sell reusable software components to external consumers. We suggest that the legal shift from copyright to patent protection for software may encourage such transactions. We first describe the economics of a hypothetical software component market and then examine the incentives that various legal regimes provide to software developers who engage in external software reuse.

\section{A. Economics of Software Components Markets}

A market for software components requires both willing buyers and willing sellers. The buyers of software components are presumably not end users in most cases, ${ }^{206}$ but are resellers who will integrate the components into useful products for the consuming public. While the technology for sofiware integration is available today, 207 integrators must be able to obtain adaptable components to create useful products. As noted above, the initial development of modular reusable software is more expensive than the development of code from scratch. While those additional costs are outweighed by the savings from reuse of the software, the developer herself will benefit only if she is able to capture some or all of the benefit from the consumers who reuse the software. Without legal protection for the design of reusable software components, producers will not be able to capture sufficient profits to justify the cost of the design refinements essential to the creation of reusable software components. ${ }^{208}$ Further, software developers who do not want to sell components to integrators can continue to "self-integrate" by writing their own code for an entire integrated program and selling it directly to end users. While self-inte-

202. See ASSET Electronic Marketplace (last modified Oct. 30. 1996) Atrip://source.assect.conv WSRD/eloctronic-marketplece. humls.

203. See. e.g.. Soffbank Web Martes, INpo. Wk.. May 27, 1996, at 26 (reponing the unveiling of online software component marketplace).

204. See Stitch Ups: Software, supra note 3, at 99 (reporing that these issues are the near term ocus of the first $\$ 40$ million of projects under NIST's sofiwere components program).

205. See generally GAO Remont on Sortwake Reuse, supro note 19 (discussing the neod for 206. In some cases end usen

assemble them for their own use. The Defense Depertment considered such a buy components and See SAmuzison, supra mote 65, at 70-71. 207. For one example. soe Subra Charrand, Pasenis: Compuser Cade Has Kept at Bay Many
People Who Wanted so Creose Their Owin Programs. No More. N.Y. Times. July 15, 1996. at D2 (describing new lecturology of "elestic objects." edaptable bundles which permit the integrator to com208 see Samueriting code of hes own).

208. See SAMUelsos, supra note 65, at 70-71 (explaining that software developers would not have an incentive to develop "perfect" coole if the Department of Defense had unlimited rights to reuse reusable). 
gration is less efficient for society than extemal software reuse, software developers will produce and sell their components to others for reuse only if they

One approach to solving this public goods problem is to give strong intellectual property protection to software developers. For example, one might confer on the first developer of an idea or piece of code a perpetual right to exclude others from using that code or anything similar to it in any way and for any purpose. However, every scheme of intellectual property protection has costs as well as benefits. Legal protection that is too broad or too long lasting may have a detrimental effect on subsequent innovation. If, for example, the owner of intellectual property rights in a software component refused to grant others a license, 209 the inability of programmers to exploit data structures, program sequences, and algorithms would have a significant chilling effect on the development of future generations of reusable software components. ${ }^{210}$ Hence, intellectual property law strives to balance the aims of encouraging innovation and creation with the goals of protecting competition and encouraging the wide dissemination of information.211 Both patent and copyright law maintain this balance by limiting the scope and duration of protection and by setting minimum hurdles which an innovator must clear before she can obtain protection. 212

Several characteristics of the market for software in general, and for reusable software components in particular, affect how this balance should be struck. ${ }^{213}$ First, because reliability from repeated testing and use provides much of the marginal value of reusable software, 214 standardization is more important in software components markets than in other software markets. Since it is more efficient to use existing software than to develop new software, the number of competitive options for accomplishing a particular task should be smaller than in other markets. This means that the effect of legal rules

209. On the reasons why such licensing might not occur, soe Mark A. Lemley. The Economics of
improvement in Iniellectual Property Law, Improvement in Imrellectual Property Law, 75 Tex. L. Rev. (forthooming 1997) (sugesting that the high conts and uncerninty associared with intellectual propeny licensing might result in an inefficient
failure to license). 210. See Levin

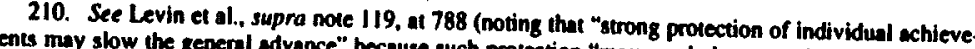
ments may slow the general advance" because such protection "may proclude competitors from makin Cumulasive Reseanch and the Pasent Law Suzanne Scolchmer, Spanding on the Shoulders of Gianis. first innovator may not expect to profis by licensing to others and 1991, at 29, 31 (explaining that inhibit future innovation and undermine the entire reseaneh lise) ond thus brond patent protoction could (making an anafogous argument with respect to reseanch line); if. Menell, suppa note 84, at 1094.95 211. For a general discussion of these tredeoffa, soe Whise $y$ interfacess).

1512 (9ih Cir. 1993) (Kozinski. J., dissenting from denlal of rehearings ong Elec. Am., Inc.. 989 F.2d 212. For a brief diacussion of some of these limitations on intertion banc).

supra and eccompanying text.

213. Professor Menell reminds us that "legal protection for computer software should be approached within a rich oconomic framework emphasizing the cumulative nature of innovetion; the broed range of kgal and non-legal methods for appropriating revenues from innovation; network effects; and S. Menell, the Challenges of Reformive legul nules for appropitaring retums io innovation ..." Peter Cotum. L. Rev, 2644, 2648 Reforming Intellectwal Property Provection for Compuser Software. 94 214. See notes 60.63 sippr against copying is stronger in software component markets than elsewhere, since much of the value resides in the reused code itself. ${ }^{213}$

Second, the software market features strong "network externalities" because the total social value of a software program increases as more consumers use it. ${ }^{216}$ The three types of network externalities are discussed here in decreasing order of strength. The strongest are interconnection externalities, in which connection to other users is itself the product being sold. The prototypical example of such interconnection externalities is the telephone network. where the product is nothing mare than the ability to connect to other customers of the network. The Internet shares strong interconnection externality characteristics, for the same reason. 217 The second strongest are interoperability externalities, which emerge where a product's value is a function of its compatibility with other products in the market. For example, in the household appliances market, an electric power plug is useless unless it connects firmly with most wall outlets. Thus, the design of electric plugs is significantly contained by the design of wall outlets (and vice versa). The thind strongest are convenience externalities, which exist where a product becomes more desirable as more consumers leam to use it, since they become less willing to learn how to use new products. For example, the typewriting industry has used the QWERTY keyboard design for over a century even though it is allegedly inferior to competing designs, arguably because training typists on a new keyboard would be too difficult and costly an undertaking for companies. 218

In general, software exhibits strong interoperability characteristics. This is particularly true for operating systems.219 In the market for operating systems,

215. The effect of this factor may be to counieract 10 some extent the problem identified in the Manifestu, supra note 2 , it 2330-64, that much of the value of a computer program resides in "know-

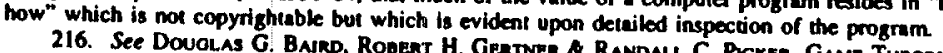
THE LAw 20B.13 (1994) (suring that the software industry exhibits significant network THeont AND Joneph Farrell \& Garth Saloner, Standardization, Compasibility, and Innovation, 16 RAND I. Econ. 70 71 (1985) ("consumers value a product more highly when it is 'compadible' with other coneumers products"): Michuel L. Ketz \& Carl Shapiro, Systems Competition and Nerwort Effects, J. Ecow. PEess. thout arailable of 98 (asserting that consumens will choose handware according to their prodictions software system). coftware system).

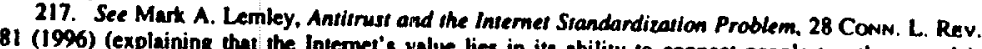
Even Liebowitz and Margolis acknowled salue lies in its ability to connect people to other people). they genernlly coution golis acknowledge the existence of network externalives of this son, though

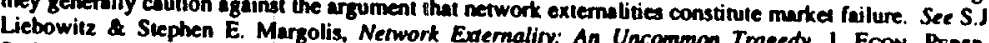
Spring 1994. Af 133. 134.

218. See Paul A. David, Cllo and the Economics of QWERTY. 75 AM. Ecow. Rev. 332, 335-36 (1985) (discussing the history and present-day economic rationale for the widespread use of the QWERTY keyboand design). Bur see S.J. Liebowitz \& Stephen E. Margolis. The Fable of the Keys, 33 J.L. E ECow. I. 4. 19 (1990) (arguing thal if another keyboard design were wuperior to QWERTY manufacturess would internalize the externality of converting typists to the superior product and would 219. "TT/ The operating

Application software products will develop all a comperibility nexus for a particular computer network. producers will develop more configuriop more programs for systems that are widely used; hardware openaing systems." Peter S. Menell. Tailoring Legal Prowection for Compuler Software. 39 STAN. L.
Rev. 1329, 1341 (1987). 
standardization is essentially inevitable. Even where a competing operating system is technically superior to the standard, consumers will not purchase the computer unless it is compatible with a wide variety of application programs. This behavioral trend depends on a large user base. Consequently, once a program becomes the standard, it remains in that position for a long time. 220 Even in the computer software applications market, where network externalities are not so noticeable, interoperability both with operating systems ("vertical interoperability") and with competing programs ("horizontal interoperability") affects consumer product selection.

There are many possible ways to meet consumer demand for interoperability. First, competitors could agree to establish a standard of compatibility among their products, or the government could require such a standard. Joint standard setting organizations are relatively common in the computer industry, although they have achieved only sporadic success.221 Second, individual companies could sell or give away "open platform" systems to encourage competitors to write programs that run on this platform. In markets exhibiting particularly high interoperability externalities, a number of companies have had some success with this approach. 222 If consumers have to choose between competing "closed" systems, however, the markers have to choose between competing "closed" systems, however, the market gravitates towand a single, de
facto standard for operating systems. ${ }^{223}$

Reusable software components should exhibit even stronger externalities than the general software industry-particularly in the context of vertical interoperability. To sell a software component, as opposed context of vertical intersystem, producers must persuade buyers that the components will be interoperable with at least one set of complementary components, and preferably with many different complementary components. ${ }^{224}$ To achieve vertical integration. vendors of different components must not only share their interface specifications, ${ }^{223}$ but they must also standardize their interfaces. ${ }^{226}$ In a market that favors interchangeable software components, vendors who design their prod-

220. The continuod prevalence of the MS.DOS opernating ayatem and its derivatives in spite of its

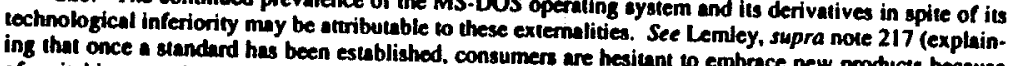
switching costs)

221. The failures of joint standerd setting groupe such as X-OPEN and the Open Software Foundation demonstrate that the participation of large industry players does not guarantee the success of 222 sun

222. Sun Microsyutems and Netscape have both done remarkably well by adopting open plat. Intermet programming language. See, and Sun with both the UNIX operating system code and the Java Operating System Riwals Gef a Boost, Sor Of. N.Y. Tives, July 24 . Execurive Computer: Microsoft's market for personal computer operating sysuema). Times, July 24, 1994, 3, at 7 (describing the

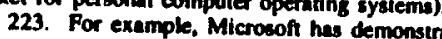

systems market with its MS-DOS standerd and subsequent refinements to dorninance of the operating supra.

224. See David d. Teoce, Profulng from Technological Innovation: Implicalions for Integration, Collaboration, Ucensing and Public Policy, is Ras. Poi' $Y 285,288$ (1986) (describing how softwan, Innovators may exploit thetr products' compatibility with other computer components to appropriate 223 , their creationa).

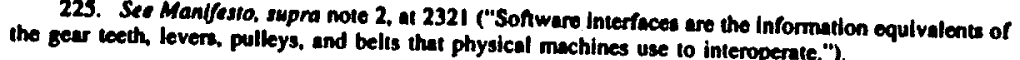

ucts according to the industry stundard benefit not only from consumer interes but also from cheaper and more accessible parts and servicing. 227 Thus, Matutes and Regibeau have persuasively shown that product compatibility encourages the development of component systems, allowing consumers to assemble their own products from interchangeable components. ${ }^{228}$

A market for interchangeable software components, then, requires two conditions. First, producers of software components must hold relatively strong intellectual property rights in the individual components themselves. Otherwise, they risk losing their profits to free riders by selling their components to software integrators on the open market. ${ }^{229}$ This follows the discussion in Pan III.A. ${ }^{230}$ where we noted that reusable components may cost more to produce than normal code. Free riders could exploit reusable components, because vendors will likely distribute them in source as well as object code form. If intel lectual property protection is relatively weak, vendors will not be willing to license their source code to potential competitors. Second, purchasers of software components must be able to use them with complementary components from other producers. Software components must either have "plug and play" compatibility, or purchasers must have the right to adapt the components to work with complementary goods. ${ }^{231}$ Absent interoperability, the interconnection between software components will remain a rarity outside single, vertically integrated companies.

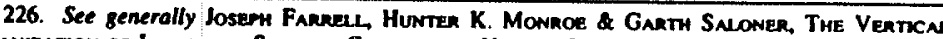
Oroanizatron of Industar: Systems Competmon Versus Component Competmon (U.C. Berke. ley Program in Law \& Econ., Working Puper No. 94-12. 1994) (describing the economic consideration that determine whether competition in an industry will occur at the component level or at the integrated

227. See Farrell \& Saloner, supra note 216, at 70-71 ("IA] complementary good (spare parts, servicing. software ...) becomea cheaper and more resdily available the greater the extent of the (com-

228. See Cavined

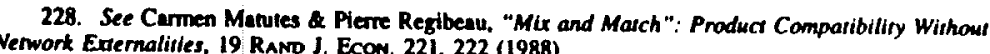
229. Exernalities, 19 RAND J. Ecow. 221. 222 (1988).

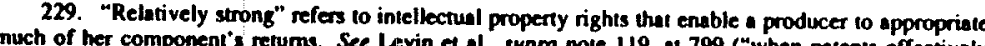
much of her component's retums. See Levin et al., supro nole 119 . at 799 ("when patents effoctively royaliy income"): Thomas M. Jonde \& David J. Teece, Innovarion. Cooperation and Antive in securing

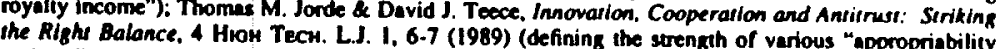
regimes"). Where the easential value of the sof ware component is contuined in the literal code itself.

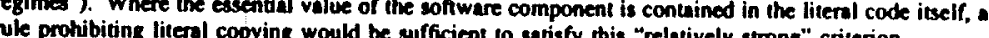
230. See notes $90-94$ supra and eccompanying rext. 231.

Where physical machines are built from physical structures like gears, wires, and screws, programs are buils from information structures, such as algorithms and data structures. In

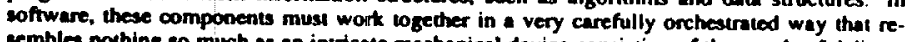
gean and tevers move at juar the in mechenical device, the gear toeth must mesh exactly. and levers muss

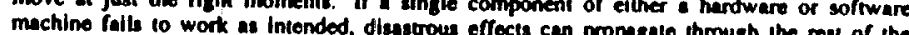
machino folls tho work ma inconded, Manivesto, suppo note 2 at 2321. 


\section{B. The Impact of Legal Rules}

Unfortunately, the Iraditional legal rules protecting computer programstrade secret and copyright-do not exhibit these characteristics. Under trade secret rules, designers must make "reasonable efforts" to conceal their trade secrets from competitors. ${ }^{232}$ If the producer discloses the secret, or if his competitors generally know or can readily ascertain the secret, the producer loses trade secret protection. Consequently, trade secret laws encourage designers to build "fences" around their secrets. ${ }^{233}$ Producers build these fences by disclosing information sparingly and imposing stringent conditions on a licensec's right to use or further disclose the secret, particularly to the producer's competitors. These are not the characteristics likely to lead to a market in tradeable software components. Ultimately, by discouraging designers from sharing interface information with each other, trade secret laws retard the software industry's move toward market-wide vertical interoperability. ${ }^{234}$

Copyright law also discourages the development of a market in tradeable software components for two reasons. First, strong copyright protection, like that generated by the decision in Whelan Associates v. Jaslow Dental Laboratories, ${ }^{235}$ extends to both literal and nonliteral aspects of a completely integrated computer program. According to some courts and commentators, this means that the developer can protect the program interface elements, ${ }^{236}$ and possibly the program languages, ${ }^{237}$ as well as the code itself. Further, courts do not uniformly permit competitors to copy vertical interoperability interfaces, even where an interface constitutes an industry standard. ${ }^{238}$ Thus, if broadly inter-

\footnotetext{
232. See notes 103-110 supra and accompanying lext (discussing strategies for disseminating sofiware without secrificing its trade recret status).

233. However, trade secret laws may enable producens to build smalles "fences" than they would need to in the absence of any intellectual propenty protection. Under inde secret laws, 10 bring en action for misappropriation a producer need only demonstinale "reasonable effors" to protect secrecy. Thus. inde secrets law erguably helps prevent wasteful overapending on secrecy measures. See Romest $P$.

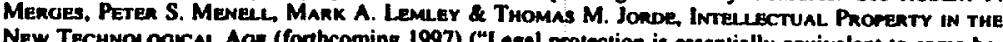
New TechnOLOOCAC Aae (forthcoming 1997) ("Legal protection is essentielly equivalent to some benevolew third party - c.8. The government-adding on to your [imperfect) fence to make it totally counge rather then encournge diessemination of information. courage rather than encourage dissemination of information.

234. Trude secret liw does permit reverse engineering to obluin the secrets contained in commermeans of accessing information necessary to echieve interopere bility. See nores $111-112$ supres and accompanying text.

235. 797 F.2d 1222 (3d Cir. 1986).

236. See. e. 8. Apple Computer. Inc. v. Franklin Compuler Corp., 714 F.2d 1240, 1253 (3d Cir. 1983) (holding that copynight is avaliable to an operating ayssem uniess there is no other way to express The idea behind the operating system). As noted above, however, most courts and commentutors reject grenting nonliteral expression such broad copyright protoction. See notes 145-151 supra and sccompaying text.

237. See Lotus Dev. Corp. v. Papertack Softwero In*1. 740 R. Supp. 37, 34 (D. Mess. 1990) (suggesding programming languages may be copyrightuble as long as the language is "merely an original Dev. Corp. v. Borland In't', Inc.. 49 P.3d 807, 815 (14 Cir. 1995) (nejecting District Court's conclusion in 1 relaped case). off "d by an equally divided Court, 116 S. C. 804 (1996).

238. For example, in Sega Enserprise Ld. v. Accolade. Inc., 977 F.2d is10 (9h Cir. 1992), ofren citod as the keading decision favoring interoperability, the court actually addreased only the kegality of intermediase copying to facilitute reverse enginecring. leaving open the question of whether the copying
}

preted, copyright law may empower owners to control who designs interoperability interfaces compatiblr with their components.

Broad copyright protection for interfaces increases the transaction costs of building integrated programs from purchased components. ${ }^{239}$ To build an integrated program a manufacturer must not only license use of the components that constitute the system, but also the rights to adapt the interfaces associated with each component. Where two components from different manufacturers were being integrated, the integrator would need permission from both manufacturers to adapt the components so they worked together. Furthermore, original software developers may use strong copyright protection to control data's migration path by forbidding transfer of the original program data to subsequent, improved programs. ${ }^{240}$ Original developers may be unwilling to freely license use of their data, especially to a company whose program might compete with theirs. ${ }^{241}$ Thus, strong copyright law protection is likely to inhibit component interoperability.

This problem is compounded by the relatively harsh rules governing derivative works, which are "recast, transformed, or adapted" versions of preexisting works. 242 Section $106(2)$ empowers the copyright owner to prevent purchasers from integrating copyrighted materials into their own original works. ${ }^{243}$ Not only is it infringement of the original copyright for a purchaser to alter her copy or to create an improved version of the work without permission, ${ }^{244}$ but any

interface components in a final work violstes copyright lews. See Cohen, supra note 17, al 1135-36 (") makes little sense to allow intermediate copying where necessary to understand the requirement for interoperability, only to withhold permisssion to incorponte the copied work's functional festures to the extent necessary 10 make the reverse engineered product interoperable."); Grahom \& Zerbe, supra note 156. At 120-21 (erguing that without reverse enginecring copyright law not only grants owners convol 239. expreassion but also over the ideas bethind the expression).

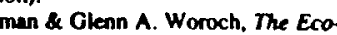
nomics of Intellectual Property Protection for Sofmware: The Proper Role for Copyright (1995) (unpub-

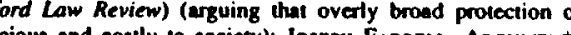

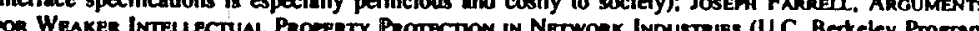
in Lew \& Econ. Working Paper No. 94-11, 1994) (expledining that protection is perticularly costly when utrong network effects exist).

240. See Hamilton \& Sabety, supra note 98, at 3, 32 (illustrating how strong copyright procection can impede migration of dout from old programs to new ones).

241. This is argubbly what was at issue in Lolus Development Corp. v. Borland International Inc., 799 F. Supp. 86 (D. Mass. 1992), rev'd 49 F.3d 807, 816 (Ist Cir. 1995) (holding that Boriand did not infringe Lotus" copyright because it copied Lotus" "method of operation" which was unprotociod by

242. 17 U.S.C. 101 (1994)

243. See 17 U.S.C. 106(2) (1994) (gnanting the copyright owner the exclusive power to wuthorize the right to prepare derivadve works based upon the copynightod work ") see also Paul Goldrein Pamela Samuelson identifies this as one of the critical berriers 10 purcheser encouraned sof in (1 reuso. See SAMvereson, supra nole 65, at 69-70.

244. In the computer softwase context. 17 U.S.C. 117 does provide purchasers with a limited nght to copy and make adaptations as an "essential slep" in the use of the program, provided the adapencion is used for no other purpose. This exception is unlikely to support adeptation or improverment for

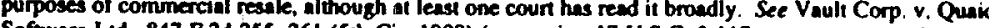

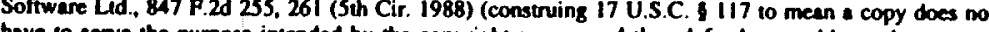
have to serve the purpose intended by the copyright owner, and thus defendant could use the copy to 
purchaser who creates such an improvement loses copyright protection for her own original expression if it is effectively integrated with infringing material. ${ }^{245}$ Ultimately, the derivative works rule discourages software designers using purchased interface components from rewriting, debugging, and generally improving software, since such alterations can potentially create an infringing derivative work. ${ }^{246}$ It therefore impedes vertical interoperability in the software market. ${ }^{247}$ ?

It is conceivable that owners of copyrighted interface elements would voluntarily license interoperability interface elements to other developers in order to sell their products in a components market. Nonetheless, licensing the right to copy and adapt a preexisting interface still poses problems. First, because copyright law recognizes a right to reverse engineer programs to achieve interoperability in some circumstances, developers may choose to reverse engineer the underlying program and develop their own code to save the cost and complication of licensing. Second, licensing interface components may prove difficult where interoperability requirements are complex, since purchaser may need to acquire rights to both copy and adapt the interface from a number of different copyright owners. And third, copyright owners of interfaces retgin limited "veto" power over any integration of their components with other manufacturers' components. This veto power will likely reinforce the reign of powerful companies over markets in which they are already vertically inte-

245. Because section 103 of the Copyright Act denies copyright only in the "part of the work" that incorporales infringing material, some infringing derivative worte may nonetheless be copyrightable in part. This is particularly me in the case of compilations, where the infringing material cap be separated easily from other pars of the work. Thus, the Houso Repon wocompanying the 1976 Act providea that though the infringer proves that publication of one of the poema was unsuthorized." H.R. Rop. No. 94 1476. at 57.58 (1976), reprinted in 1976 U.S.C.C.A.N. 3659 , 5671.

However, where copynighted malevial is intertwined with that contribured by the Infringer, the infringer losea any righte in the resulling product, even if most of the value of the work is atertbuibuble to her contribution. "IIIf the pre-existing malerial ured without permiaston 'iends to pervade the entino inc. v. Planning \& Control, Inc.. 646 F. Supp. 1329, 1340 (S. D. Ne work entirely." Dynamic Solutions, inc. v. Planning \& Control, inc..646 F. Supp. 1329, 1340 (S. D.N.Y. 1986) (quoting I Nimmes. Nimmen 1992) (quoting this Dymamic Solutions language); I Nimuconds, Inc., 794 P. Supp. 933,938 (N.D. Cal. 34.5 to -34.6 (1996); Anasusia P. Winslow, Rapping on a Revolving Door: supra nore 139. I3.06. An 3 . Parady and Campbell v. Acuff-Rose Muulc, Inc., 69 S. CNL. L. Rev. 767, 779 (1996) ("Thus Analysis of preexiating material pervades ithe derivadve work, the derivative nuthor acquires po copyrighis when the matrer how creative or inventive the derivative use.").

246. See J.H. Reichmon, The Know-How Gap in the TRIPS Agreement: Why Soptware Faned Badly, and What Are the Soluslons, 17 HASTinos Comm/ENT. L.J. 763.780 (1995) (software developer might use the right to prepare and authorlze derivative works 10 claim ownershlp over the functional aspocts of subuoquent compuver programa): Pamele Samuelion. The Need for Reform of the Software (1966) ("Because of its ing 'old' versions every year, on even every ceveral months."). 247. See Lemley, supra note 209 (erguing for a change" in tho

line with the rule in patent cases). grated. ${ }^{248}$ Finally, various complications, from transaction costs to uncertainty to strategic behavior, may preclude an efficient licensing transaction. ${ }^{249}$

The second problem with copyright law is that it only protects the code of a copyrighted component and permits competitors to copy the ideas underlying that component. It therefore encourages competitors to write their own code to implement the basic ideas behind a another's program. This amounts to recreating code, precisely the result we would like to avoid in creating a reusable software market. If subsequent developers can capture the know-how of a program by observing it and then writing a competing program, and if that knowhow (rather than the code itself) is the most valuable part of the program, ${ }^{250}$ competitors will write their own programs incorporating that know-how and save the cost of purchasing the component, ${ }^{251}$ Arguably, prohibiting direct copying but permitting redesign, as copyright does. encourages software reinvention.

In sum, copyright law stunts the development of a reusable software market in two related ways. First, copyright law vests control over derivative works in the auithor of the original copyright program, and threatens to give the copyright owner complete control over the creation of compatible programs. This makes it difficult for integrators to alter purchased components to make them compatible with a variety of different systems. ${ }^{252}$ While original developers might license the right to adapt their components, copyright supplies powerful incentives for those developers to keep a tight rein on the subsequent use of their components. ${ }^{253}$

Second, one does not necessarily need a license to capture the bulk of a component's value. One can achieve this goal by reverse engineering the program or analyzing it to uncover and copy its unprotected ideas and functional aspects. Understandably, subsequent users generally choose to write their own program code and capture this value rather than license the original. Unfortunately, this means that competitors must engage in software reinvention rather than reuse.

248. See, for example, Arart Games Corp. v. Nintendo of America, Inc. 975 F.2d 832, M45.46

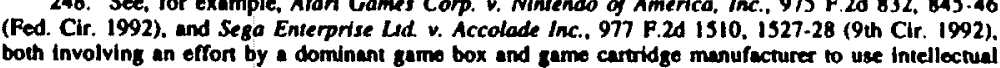
properny righis to prevent competition in their manter for game cartidges. See also Semuelson, supro note 246, at 44 (expreasing skepticism that reuse would be ensy to achieve because of copyright owners." relative position of power).

249. For more detail on this issuce, soe generally Lembey, supra nove 209.

250. See Manifesto. supra note 2 , it 2332 -33 (concluding that most program value does in fact stem from know-how unprotectiod b sopyright law).

25I. Specifically, they will in so if a license for the component is unavailable or is cosstier then

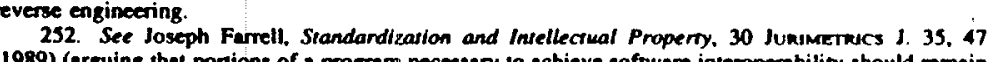
(1989) (arguing that portions of a program necesancy to achieve software interopernbility should remain 233. In fact, copyright law may also encournge sofwwere developers to sell integryled systems mather then individual components by giving protection to a compilation of components which are individually uncopyrightuble. See. e.8. Apple Computer. Inc. v. Microsof Corp. 35 F.3d 1435, 1439. 1446-47 (9th Cir. 1994) (ketating that a collection of uncopyrighiable user intericce elements coust as a whole roceive minimal protection ageinst vintually identical copying). cert. denied, $115 \mathrm{~S}$. C. 1176 


\section{Software Patents and Components Markets}

Patent law is more consistent with the development of a components market. Unlike copyright and trade secrecy, patent rights are "strong" in an absolute sense. They do not depend on limited disclosure or on proof of copying. but extend to any use of the claimed invention. Because of their strength, patents eliminate a major problem with copyright protection: the incentive to reinvent software in order to appropriate the ideas in the software component without infringing the original producer's copyright. 254 If an integrator wants to use the ideas in a patented software component, he must license the patent from the producer of the component. ${ }^{25 s}$ And once the existence of patent rights for components forces the parties to the bargaining table, the transaction costs of licensing the code itself drop dramatically. Why should the integrator license only the idea and then reinvent the code from scratch, when he could license the whole thing in one transaction?

254. Certuin propoeals for sui generis legal protection of computer prognems could also solve this problem. See Manifesto, supra mote 2, at 2312: of. Richard H. Stem, On Defining the Concept of in 23 AIPLA O.J. 401. 519-23 (1995) Rights in Algorishms and Oiher Abstraci Computer-Relared Ideas. patem" ayotem). However, because as a prectical matrea of soch propose infringement lests under a "petty have chosen to focus on pavent low. See Jane C. Ginsburs, Four Reasons and a Panadox. The Mantede

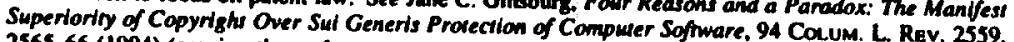
2565-66 (1994) (arguing that software proprietion will reatu replecing satisficcory copy. L. ReV. 2559 with the Manifesto's proposed compulsory license registntion). See senerally Paul Goldevein Com ments on A Manlfesto Concerning the Legal Prosection of Comperer Programs, 94 Coldsum. Com 2573 (1994) (ariculating alsecks on its foundational premizes and its operational deuils thet the Mevi. festo would need to withstund if it enlered the legislative marketplace).

255. See Mart Aaron Paley. A Model Software Perite Parents Act, 12 Santa Clara Commurer Hion TECH. L.J. 301,328 (1996) (explaining that Microsof OLE rechnology allows applications based on prebuilt components which "increases the need for mandatory licensing because it is so casy to put little program inside another program"). Classic oconomic literature suggeats that vesting atrong put erty entillements in a single panty will encournge that periy to make efficient use of the property. See. e.8. Harold Demsetz, Toward a Theory of Property Rights. 57 AM. Econ. Rev. 347. 354-56 (1967) Rob Merges. Fies Merges inellectual Property and ine Rev. 1570 (1995) (terepenty and the Casts of Commerclal Exchange: A Review Essay, 93 MicH. L. package in which entitements are owned by different panel. When the property is part of a lurger Compare lan Ayres a Eric Talley, Solomonic Bareal parties, the problem becomes more complex. Coasean Trade. 104 Y,es L.J. 1027, 1029-30 (1995) (noting that in the context of imperfoct borcilitate dividing entitements to property through lisbility rules may roduce the incent of imperfoct bargaining. and induce each bargainer to reveal more information) wish Louis Kaplow \& Steven Stravell. Do Liabil-

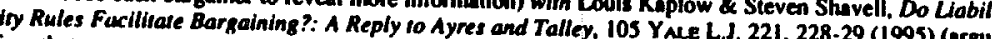
ing that strong property entitlements result in grealer bargeining-reluted welfare gains than divided entittements in the coniext of imperfect bargaining). On the development of market mochanisma that mimic lisbility nules, compare Robert P. Merges, Contracting inso Liability Rules: Instilutions Support. Ing Transactlons in Insellectual Property Rights, 84 CAL. L. Rev. 1293 (1996) [hereinafter Merges, Lver the value of intelloctual estublishing property entitements is the only way to get parties to bargain for Cwmularive Systems Tectunology, 94 Cow) with Richund R. Nelson. (miellectual Property Protectlon lectual property protection in multipary bargaining enviromments may s94) (claiming that strong intel. learr, Justice Douglas Was Right: The Need for Congresslonal Action on Software Parents. Lee HolQ.J. (forthooming 1996) (wuggesting that buying comprestitiol Action on Software Patenis, 23 AIPLA may serve as a form of insurance agalnst paicent infringement claiment. mather than reinventing them.
Properly interpreted, patent law should also help solve the interoperability problem. 236 Most patentable inventions in computer science are not whole software programs but particular ideas or approaches to specific problems. Entire software programs are unlikely to be protected by patent law, but the components themselves (and even smaller "subcomponents") will probably qualify for patent protection. Under patent law, the "invention" of putting two components together should ordinarily fail to satisfy the requirement of nonobviousness, at least if the patent office evaluates obviouness using the standard of a reasonable programmer skilled in the relevant art. ${ }^{297}$ Thus, patent protection for innovative components should provide both of the basic requirements for the development of an interchangeable components market: strong protection for each component itself and little or no protection for vertical interoperability elements. ${ }^{258}$ Licensing should be easier under a pure patent system than under a pure copyright system, since patent law precludes the overlapping claims to interface elements that copyright law produces. Over the longer term, patent protection will also help sni: the problem of secret code, since patent owners will have to disclose their inventions to the public to obtain a patent, and those inventions will be free for all to use once the patent expires. ${ }^{259}$

Further, dividing property entitlements by patenting software components may leave the developers of integrated software programs no choice but to negotiate licensing agreements with others in the industry. Because programming inventions tend to be directed toward particular techniques for solving defined problems, one company will likely not possess all of the rights it needs to produce an integrated software system. It is more likely that different software developers will patent different techniques, algorithms, or program routines, and companies will have to obtain licenses from different developers in the process of producing an integrated system. For this reason, the concern that software patents will allow large companies to "lock up" rights to produce integrated software systems ${ }^{260}$ should be alleviated by the distributed owner-

256. See text accompanying notes 155-156 supmo.

257. In practice, patent law has been lentent toward scemingly obvious combinations in the software industry. See notes 287-292 infra and accompanying text.

258. As Profeseor Merges explainod:

Withoul the eccurity of a properny right granted by the government, sofiware suppliers in Japan would be losthe to leave he profective contractual sphere ithey sharod with their captive

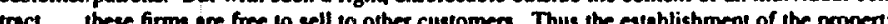
right. ... makles] such innsactions feasible

Robert P. Merges, $A$ Comparative Look at Property Rights and the Software Industry. in THE INTrenNA

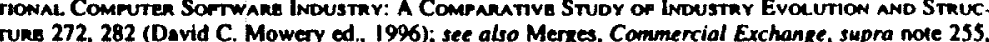
Tune 272. $1589-90$.

259. See 35 U.S.C. 112 (1994) (providing that the patent spocification must describe the inventhollear, supra note 255. Those who meintuin code as a secret may lose their rightis to that code to subsequent patentees. Regarding the problem of socret prior art, sec note 286 infra.

260. See John Swinson. Copyright or Parent or Both: An Algonthmic Approach to Compuser

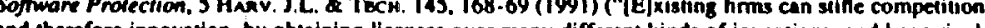


ship of software patents and the consequent routine licensing of those patent rights. 261

Finally, in some respects patent law provides initial developers with less control over others' derivative works than does copyright law. ${ }^{262}$ While improving a patented invention still requires a license from the owner of the original invention. substantial improvers can obtain their own patents for thei improvement. Substantial improvers may thus take advantage of the rule of "blocking patents," under which either party can prevent the other from using the improved invention unless the parties negotiate a license. ${ }^{263}$ The reverse doctrine of equivalents, which excuses literal patent infringement in certain cases of radical improvement, may also benefit some improvers. ${ }^{204}$ The additional bargaining power which these rules give the improver should encourage others 10 improve on prior inventions. This patent law rule contrasts with the copyright rule, under which the improver loses the value of his unauthorized improvements if they are integrated with infringing material. Further, patent law should encourage licensing between original software developers and those who adapt or improve the original code, 265 a critical element in the development of a software components market.

We therefore believe that a pure patent-based system is more conducive than a copyright-based system to the development of a market for reusable software components. Indeed, industries which have characteristics similar to computer software but which already rely primarily on patent protection (such as the semiconductor industry) have actually developed in this fashion. ${ }^{266} \mathrm{An}$ -

out of the market by refuaing to license, by charging excessive license fees, or by forcing rivals to waste resources inventing inferior processes that eccomplish similar results in less efficient ways.").
261 . See generally Merges, Lablilty Rules, supra note 255 (arguing that firms mitigate the effect of property nules in intellectual property cases by "contracting into" group licensing ayslems).

262. See Samuelison, supra note 246, it 34-35. Thin result may woem odd. given that petent rights are in most respects etronger than copyright rights. Paten law's leniency toward derivative works may atem from the different goals and origins of copyright and patent law. While patent law has traditionally cused more attention on the "moral" righus of to improve products sold, copyright has generally fo. cused more attention on the "moral" righis of authors over their creutions. See generally Edward J. Aushors, 23 OA. L. Rev. 1 (1988) (providing a madionile for greater protection of the Moral Rights of the right of perzonality in case law): Robers Rosenthal Kwall, Copyright and ihe Moral Right: is an American Marriage Possible?, 38 VAND. L. Rev. I (1985) (arguing that the 1976 Copyright Act should Include provisions provecting a creator's moral nighes as distinct from the oconomic rights of copyright holders). Cf. Margaret Jane Redin, Property and Personhood, 34 StaN. L. Rav. 957 (1982) (suggesting that fungible property ights athould yleld to personhood interesu where the rwo confict). But see Lemley, supra note 209 (nejocting the moral righis jusdfication for different rules reganding improvements in 263 copyright low.

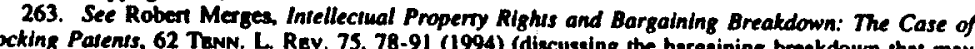
Blocking Patents, 62 TanN. L. Rev. 75, 78-91 (1994) (discussing the bargaining breakdown that may

264.

265. See ld. at 76 (stating that "the voluntary licenaing in these canes").

Valley and Routs 128 Saxenian, Reorowne Advantaoz: Curture and Competmon in Sulcom LeY AND Routs 128, at is (1994). Sexenian writes:

Semiconductor firma, following the model wex by ATaT's Bell Labs with the transistor, liber-

ally crosa-licensed ithetr parents to competiton during the industry's first three docades. This
naLee Saxenian attributes the relative success of the Silicon Valley computer and semiconductor industries to their greater willingness to shift from intemal self-sufficiency to reliance on purchasing hardware components from external sources, often from competitors. ${ }^{267}$

For the sake of argument, we have drawn a sharp contrast between copy. right and patent regimes. In practice, however, the role of legal incentives in the software industry is more complex. In the first place, not every new software component is eligible for patent protection. Because of the strong rights patent law provides, the standards for obtaining a patent are higher than those for obtaining a copyright or a trade secret. 208 Some, perhaps most, new components will fail to meet these standards because they are obvious to one skilled in the art. 269 These will be essentially commodity components-interchangeable components produced by a variety of "manufacturers," which do not typically exploit advances in the state of the art. The linked list manipulation component suggested earlier, ${ }^{270}$ which presumably could be implemented by any moderately skilled programmer using a first semester computer science text as a guide, exemplifies such commodity type components. Because the linked list component is probably unpatentable, the analysis in this part would not apply to that component.

Even if many software components cannot be patented, patent law may still create powerful incentives for component licensing. If a typical integrated program contains six software components, a competitor with a patent on any one of those components can withhold permission to use his component and thus prevent development of the program. Integrators thus will have to negotiate with such patent holders to obtain permission to use the patented component. Even a modest number of software patents will force licensing in a significant number of cases over time. And as noted above, the number of software patents in force is already quite substantial. ${ }^{271}$

The fact that patent rights to software techniques are likely to be owned by many different companies triggers the "blocking patents" situation, further encouraging licensing. It also helps allay concerns that software patents will simply perpetuate market dominance among companies that have controlled the copyright-driven software industry. Single firm market dominance is much harder to achieve when many companies control different (albeit small) pieces

pooling of inventions and devices ensured that technical advances diffused quickly and the industry as a whole progressed. regandless of the fate of any individual firm. In Rober Noyce's wonds: "Without (cross-licensing patents), no firm could be using the latest technology in all areas. One might be using epituxy without diffusion, another oxide masking but nor

267. See id. al 141-42 (discussing Sun Microsystems' use of outside suppliers for herdware, such as integraied circuits and disk drives)

268. See noles 135-138, 162-171 supra and accompanying texis.

269. See 35 U.S.C. 103(a) (1994).

270. See text accompanying note 98 supro.

271. See note 173 supra. 
of an industry. The decentralization achieved by dividing the propeny entitlement will drive software companies to license components to each other.

A second complicating factor is that the increase in the availability of patent protection for computer software has not eliminated the availability of patent right protection 272 we availability of copyAt minum, public copying for commodity type components that do not qualify for patent protection. Without such minimal protection, an imitator could immediately copy the component and enter the software component market at a lower cost than the initial producer of the code. In the case of many reusable software components, copyright protection against literal copying provides sufficient reassurance to producers creating reusable components. The market does not value commodity-type components for the new design concepts they contain; by definition, they merely implement well-known ideas in code. Thus, one of the primary reasons why copyright protection discourages reuse-the ability of competitors to take the design concept without taking the code-does not apply in the case of commodity type components, since their value resides entirely in the copyrighted code. In short, literal protection of source code and object code creates a sufficient incentive for producers to provide some commodity reusable components in the external market. starting to be disseminated over the Internet. ${ }^{273}$ Limiting copyright protection also prevents the developer from controlling program interoperability interfaces, and therefore avoids some of the problems associated with stronger copyright protection.

A third factor is that a surprisingly large amount of code is produced as "freeware" or "shareware." This software is intended to be shared and distribution over computer networks is encouraged. Sharewgre is shared and distribuearly in the development of any given software market, such as the market for computer games in the early 1980s and the current market for Internet "applets," executable programs written in Java. Sun Microsystems' new programming language. Because of freeware and shareware, we can reasonably assume that some software components will be free for anyone to use in producing integrated software systems. Such free components will be particularly valuable to entrepreneurs building new programs.

In sum, we do not suggest that computer software should switch from a pure copyright to a pure patent system, or that the relationship between legal

272. The new patent guidelines governing computer software make "functional" aspects of pro. grams patentable, and "functional" elements of a work are itheoretically unprotected by copyright. See Computer Assocs. Ini'I, Inc. v. Altai, Inc., 982 F.2d 693, 714 (2d Cir. 1992). Thus, the particular Lespecta of a computer program eligible for patent protection are arguably uncopyrightable. See also preclude copyright protection for the sumg that patent protoction for functional sofrware etements should wheclude copyright protection for the same elements). Under this argument, only the functional elements 273. One fuctor thas has favored the development of auch oompone entire computer program. ming environment is the development of the Jova progranth components in the Internet programmore amenable to component integration then stundand promming language, which is in some respects

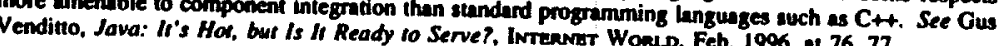

incentives and the reuse of software is a linear one. We do believe that, for the reasons given, patent law is better suited than copyright law to an economy in which software components with a significant inventive aspect are externally traded, and that one effect of the current trend towards software patents will be to encourage reuse of such components. Further, we contend that weak copyright protection for software components will better encourage a software component market than would strong copyright protection. In the next section, we examine the consequences of developing patent protection for software components markets.

\section{The Outlook for Developing a Reusable Component Market}

Modern intellectual property prolection demonstrates encouraging trends from the perspective of a market for reusable software components. A more limited form of copyright protection for software has replaced the strong copyright protection evident in a number of court decisions in the 1980s. ${ }^{274}$ Courts are much more skeptical of broad copyright claims to the "look and feel" of a computer program. Moreover, virtually all courts that have considered the issue have taken steps towards creating a right to copy program interface elements, at least when necessary to achieve vertical interoperability. ${ }^{273}$ Finally, although a competitor who copies portions of a producer's program occupies a more precarious position under the law than a downstream user, at least two courts have suggested that copyright in program components cannot be used to block either horizontal or vertical interoperability efforts by competitors. ${ }^{276}$

As the scope of copyright protection has diminished, the scope of patent protection has expanded.277 While uncertainty surrounding the patentability of software components has no: sntirely disappeared, both the PTO and the Federal Circuit have allowed suftware patents in a wide variety of circumstances. That decision would be hard to reverse at this point, even if the PTO or the Federal Circuit were willing to do so.

Despite this trend away from broad copyright protection toward expanded patent protection, some problems remain. Some large integrated computer software firms are seeking both to reexpand copyright protection for

\footnotetext{
274. See generally Lemley, supra note 142 (discussing this development); see also notes 149-16 upra and accompanying text.

275. See nole 156 supro and sccompanying text.

276. See DSC Communications Corp. v. DGI Tech. Inc., 81 F.3d 597, 601 (Sth Cir. 1996) (hold ing that the district court properly declined to issue preliminary injunction against compeny that bootod up its competitor's microprocessor cand): Lotus Dev. Corp. v. Bocland Int'I. Inc.. 49 F.3d B07, 818.19 mand hiersechy for apget defendant did not infringe competitor's copyright by copying menu com The unsenied nature of the law with regent aff d by an equally divlded Coun, 116 S. Ci. 804 (1996) compecition and intellectual properny. Recolution of this copying arises from the conficting goals of relevant intellectual properny low, but also antitusest law. For an aquires a court to consider not only achieve interoperability is nocessery where the copied prognm thes become a de focto cundering to Pamela Samuelson. Software Comparibility and the Law, Comarunications of The faclo sunderd, soe

277. See notes 149-162, 196 supra and eccompanying texts.
} 
software 270 and to circumvent the rules of copyright altogether by expanding contract doctrine to cover shrinkwrap licenses which prohibit copying or adaptation. 279 Either or both of these developments may cause the industry to return to a reliance on expansive copyright-like protection.

Further, the trend towards allowing software patents has not been coupled with a robust mechanism in the PTO to distinguish between obvious and nonobvious inventions. This problem has several parts. First, because it long considered software unpatentable, until recently the PTO did not employ examiners experienced in the software arts. As a result, many of the patents issued during the 1980s were not examined by those most skilled in the subject matter of the applications. ${ }^{280}$ Second, very little of the relevant prior art is cited in software patent applications.281 Professor Julie Cohen explains:

[I]n the field of computers and computer programs, much that qualifies as prior art lies outside the areas in which the PTO traditionally has looked-previously issued patents and previous scholarly publications. Many new developments in computer programming are not documented in scholarly publications at all. Some are simply incorporated into products and placed on the market; others are discussed only in textbooks or user manuals that are not available to examiners on line. In an area that relies so heavily on published, "official" prior ar, a rejection based on "common industry knowledge" that does not appear in the scholarly literature is unlikely. Particularly where the examiner lacks a computer science background, highly relevant prior art may simply be missed. In the case of the multimedia data retrieval patent granted to Compton's New Media, industry criticism prompted the PTO to reexamine the patent and ultimately to reject it because it did not represent a novel and nonobvious advance over existing technology. However, it would be inefficient and probably impracticable, to reexamine every computer program-related patent, and the PTO is unlikely to do so. ${ }^{282}$

278. The likely test caue for ithis effor, Lowus v. Borland. fizzled when an equally divided U.S. Supremo Court affirmed the First Circuit Coun of Appeals' judgment in January 1996. Lotun Dev. Corp. v. Borlond Int'I. Inc., 116 S. C. BO4 (1996).

279. Shrinkwrap licences ave license provialons that vendon package and "ahrinkwrap" with their producta, intending to bind customens 10 those cerms through thetr opening of the plastic wrap and use of the product. Such shrinkwrap licenses are typically includod in software products. See Mart A. Lem. ley. Invelleciual Property and Shrinkwrap Licenses, 68 S. CNe. L. Rev. 1239, 1241.42 (1995). In 1996. a cour held for the first dime that ahrinkwrap licenses were enforcenbie, and could provido copyrightlike protection even to uncopyrightuble works. See ProCD. Inc. v. Zeldenberg. 86 F.3d 1477. 1452-53 (7th Cir. 1996). A don proposal to create a new Article 28 io the Uniform Commercial Code would validare such strink wrap license provisions by statule. Both ProCD and the Arricle 2B draft run counter 10 the preveliting trend among courts to refuse 10 enforce shrinkwrep likensea. See Lemley, supra, at 1243 \& n.23 (discussing cases). For a proposal on how to treat ahrinkwrap liceness that aller foderal 280. For the romewhes Merges. Commercial Exchange, supra note 255, at 1612.13.

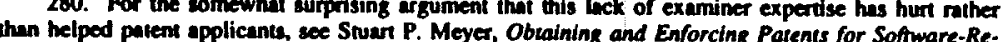
lased Inventions: Awoiding the Plifalls, 5 Sortwanke L.J. 715 (1992).

281. "Prior an" is any relevant knowled ge, ect decription, or pient which produce the invendion in question. See Mooney v. Brunswick Corp., 663 F.2d 724, 733 (7th Cir. 1981) (ciding 35 U.S.C. 102).

282. Cohen, supra nowe 17, a 1178 (ciutions omitted). Professor Cohen's argument is aupponced by a rocent sludy of coftware paients, which concluded that "the most relevant an is not being consid-

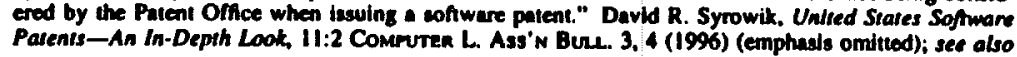

A new approach to this problem is the creation of private "prior art" databases designed to make available for search those software techniques that have not been patented and are not otherwise available. ${ }^{283}$ In addition, database groups such as the Software Patent Institute propose to address complaints about the quality of software patent examinations by offering educational services to patent exar iners. ${ }^{284}$ Online collections of software prior art may help to alleviate some, but not all, of the problems Professor Cohen describes.

The amount of prior art will increase as the large numbers of software patents that are currently being issued become prior art themselves, and can be cited against newer patent applications. Unfortunately, these software patents can be cited as prior art only if they can be found, and current classification techniques within the PTO make locating software patents difficult. ${ }^{285}$ In addition, much of the prior art which does exist, particularly source code manufactured by competing developers, is still maintained as a trade secret. There may be no way for the PTO to find and cite this material to oppose a patent claim. ${ }^{286}$

Finally, the patent laws are extraordinarily lenient towards inventions that consist of combining two different, previously known ideas to produce a new invention. 287 This lenience results in the issuance of thousands of patents for the seemingly obvious idea of taking well-known physical world practices and

Garfinkel, supra note 173, at 105 (discussing the difficulyy of searching for prior art involving software

283. For a list of sources of prior an in the software industry, soe Gneconr A. Stomss. Sortwane Patzents 122-147 (1995).

284. Id. at 141.
285. See id. at $121-22$ (noting that current classification of software is too large to be useful). A study by one of the authons discovernod that soffwere patents were scantered throughoul the PTO cinssifcation scheme. See Mark A. Lemley. An Empirical Study of the Twenty-Year Patent Term, 22 AIPLA Q.J. 369. 404 -05 \& n. 100 (1995)

286. Cohen, supra note 17. al 1170 . Secret prior an causes other problems for the patent process Por example, exploiting an invention by treasing it as a trade eocret can amount to concealment under coction 102 (E) of the patent codo. If so, the "conceallod" inventon cannot be offered as protor ant to bar a Slosberg. Beware! Trade Secret Soptware May be Palensed by a Laver Inventor. Commures Law. Nov.

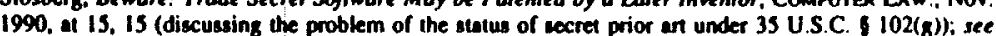

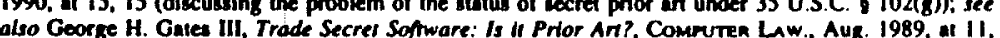
II. In the era afier Govischath v. Benson, 409 U.S. 63 (1972), this was not much of a threat, ance patenis for cofiware wero gonerally not avallable. See Himansatus S. Amin, The Lack of Protection Afforded Software Under the Current Insellecimal Property Laws, 43 CLev. St. L. Rev. 19. 24-25 (1995). Now, however, assuming an inventor is clever enough to phrase ther potent claims in accondance with cases such as in re Alappat, 33 F.3d 1526 (Fed. Cir. 1994), and in re Iwaheshi, 888 F.2d 1370 (Fed. Cir. 1989). patent protection is available. The result is that lacer inventors may be able to cleim potent priority over earlier inventors of the same sofftware. See Smith \& Slosberg. supna. at 21-22. Section $102(\mathrm{~g})$ not only makes it impossible for the first inventor to obtwin a patent, but also directs the Patent Office and courts to dissegard the first inventor's socret use when evaluming the validity of the second inventor's patent. In short, the combination of the soction 102(g) rule and the growing role of patents for a long ime. In some such cases, the second inventor will have berred the first inventor frotn using her own invention, especially if the first inventor invented long before the socond. See id.

287. To prove that such a combination invention is obvious, the Patent Office must athow that a single prior an reference suggested that the idens be combined and that the combination is easily accomplished. See in re Vecck. 947 F.2d 488 (Fed. Cir. 1991) (holding thal a combination of prior ant is obvious if "ithe prior art would have suggested to those of ordinary still in the an that they should make 
implementing them on computers using standard programming techniques. ${ }^{280}$ The problem with combination patents is particularly significant for the software components market. One advantage of using patents to encourage such a market is that they should give strong protection to the components themselves, but little if any protection to obvious combinations of preexisting components. In practice. however, the PTO allows these obvious software combination patents. If the PTO does not pay more detailed attention to patent applications, ${ }^{289}$ the practice of trading components will become more difficult, because a single firm will be able to patent and therefore control the integration of multiple components into a software program.290 Even worse, patents may issue on the integration or translation of software components, preventing any unauthorized combination of components. ${ }^{291}$

A number of commentators have suggested that we curtail the issue of obvious combination patents by redefining the obviousness test to whether a programmer of ordinary skill in the art who desired to achieve a particular result using a computer could write such a program using standand programming techniques. If a programmer of ondinary skill in the art could do so, the new program should be prima facie obvious and therefore unpatentable. 292 This suggestion is both workable and consistent with patent cases in other contexts. Its adoption would help discourage the PTO from issuing overbroad patents which preclude the development of subsequent programs using standard programming techniques well known to those skilled in the art.

the claimed combination," and if the "prior art would also have revealod. that in ... making or carrying 288. See Cohen, supra note 17, at 1168-70. As one example, consider United Stries Patent No. 5.530.752 (entitled Systerns and Methods for Prolecting Software from Unticensed Copying and Ure). But see in re Raynes, 7 F.3d 1037 (Fed. Cir. 1993) (effirming the Patent Board's determination that simple petent for providing video information at a gasoline pump was obvioust. 289. Alc

289. Alternatively, such palents may continue to be issued but will be invalidaced by the courts. face a heavy burden of proof in showing that an issued patent is invalid. See Intel Corp. v. U.S. Int' Trade Comm'n, 946 F.2d 821, 829 (Fed. Cir. 1991) (expleining that a patent is presumed valid. invalidity must be proven by clear and convineing evidence). In addition, most licensed patents and never litigated. Thus, issuing such obvious patents could result in a myriad of unnecessary licenses. 290. By contrass, a patent system in which software patents are only issued to innovative software components is less likely than the old copyright system to enable one firm to capture a market for perticular type of integrated software program. When different companies own the patenis for the components necessary for an incegrated coffware prognm (e reasonable assumption in most sofiware markets). a developer of an integrated program will need to license the patents from different parries. Dividing the legal entitlement into pans should reduce the threat that any one firm will dominate a paricular marke. For a discussion of the effocts of such a divided entitiement, see Ayres \& Talley. Metget on

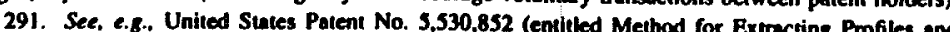
291. See, e.s. Unitod Suntes Patent No. S.J30.852 (entiled Method for Extracting Profiles and

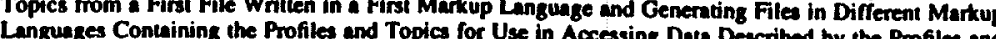
Topics) (claiming an SGML-HTML converier).

292. This is known as the "innovative progrnmmer" atundard. See Coher, supra note 17, at 1169 (describing the stundurd suggested by Richerd H. Stem, Tales From the Algortihm War: Benson 10 Iwahoshi, II's Deja Vw All Over Again, 18 AIPLA Q.J, 371,395 (1991)).
To be sure, the development of software components markets requires more than simply a properly designed intellectual property regime. Other legal rules and norms must exist for such a market to develop. For example, some mechanism must exist to permit parties to license their components at low cost to others and to divide profits made from multicomponent systems. Some recent evidence suggests that, left to themselves, industry participants may develop innovative solutions to this problem. ${ }^{293}$ Software companies' increasing tendency to conduct business transactions over the Internet also has the potential to improve component licensing, both because information about component capabilities and pricing is easily disseminated on the World Wide Web, and because parties can negotiate contract terms electronically. ${ }^{294}$ Both of these mechanisms require that antitrust law treat such cooperation among competitors more leniently than it has in the past. ${ }^{295}$ Some evidence demonstrates that antitrust law is willing to permir cooperalive arrangements among competitors where such arrangements serve a market-making function. ${ }^{296}$

There are also nonlegal prenequisites for a successful software components market. Computer scientists who think of program writing as "art" and companies that are used to producing software entirely in-house will have to change their approaches to producing integrated software programs. Established companies and experienced programmers may resist a shift towards writing software incorporating components developed by someone else because they will have less control over the final product. While such resistance may delay the transition to software components markets, it will not prevent the development of such markets. Already, the newest generation of programmers and companies is adapting to the decentralized, component based world of the Internet. Interchangeable, plug-compatible applications and system software components including Web browsers, FTP, email and news clients, Internet protocol implementations, image and motion picture viewers, and audio players compete for places in the application suites of end users. Design innovation and implementation refinement in the market for such component applications

293. See Merges, Liability Rules, supra note 255 (describing the development of patent pools in innovative industries, and copyright collectives to license music): Stanley M. Besen. Sheilh M. Kirby Steven C. Salop. An Economic Analysis of Copyright Collectives, 78 VA. L. REV. 383 (1992) (describing copyright collectives). The development of such licensing programs among competitors may actually be more likely in industries characterized by serong network extermalities, where users want to buy products compatible with those bought by others, such as the sortwere components market. See Stanley M. Besen * Joseph Fimell, Choosing How so Compele: Sirategles and Tactics in Standandization. J. Econ. Pensr.. Spring 1994, at 117. 124-25 (explaining that companies in network markets are more likely to license their lechnology to competitors bochuse of the company's desire to achieve the "industry

294. On the potential for the Intermet to reduce unnsuctions costs, see I. Troter Handy, The Proper

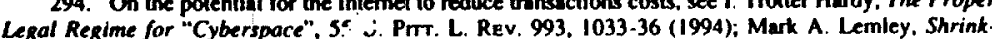
(1995).

295. See Jonte Teoce supra note 229, a 36.55 (exphining how traditional antitrust laws cen hinder innovation).

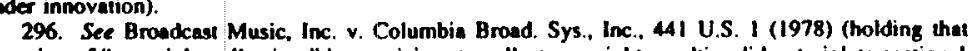
formation of "copyright collectives" by musicians to collect copyright royalties did not violate section I of the Sherman Act). For more detril on this subjoct, see Lemkey, supro nole 217. Cf. Dretter, supra note 46, at 736, 738 (suggesting that antitrust in some cases may encournge or even mandale the unbundling of compiled sofiwere products into their component parss). 
is progressing at a rapid rate, with major releases occurring several times a year. ${ }^{297}$ In addition, Java "applets" promise a paradigmatic shift in both programming and software distribution methods, allowing components to be transparently and incrementally delivered on dem Lewis predicts that "the shrink-wrapped packages that contain individual, monolithic applications are eventually going to disappear, to be replaced by objectoriented software components that are downloaded from the network." 299

\section{Conclusion}

There are powerful reasons to encourage software reuse. Reusable software is more reliable than reinvented software, and reuse is much cheaper than reinvention once the reusable component has been written. A software components market will encourage competition among producers of components as well as among integrators of different components. This will be a great improvement over the curment vertically integrated firms' monopoly of the market
for de facto standards.

Traditional intellectual property rules discourage the development of such a market, both because they discourage the dissemination of new inventions (thus encouraging internal integration) and because they encourage reinvention as a means of circumventing copyright protection. The shift from copyright to patent as the dominant mode of protection for computer software is encouraging however, because it promises to couple strong protection for novel components with a free market in interoperablility. Up until now, legal doctrine has not optimally encouraged software reuse. In this article, we offer suggestions as to how the law can encourage the creation of tradeable softer market. As legal barriers to software reuse continue to disappear, the trend toward component based software will accelerate, to the benefit of the industry.

297. Many such application components are updated monthly, even weekly, during periods of rapld developinent. The currem relense (version 2.In of Trumpet Winsock, a SLIP/PPP interfece for connecting Windows PC to ithe Intemet over dialup lines available from Trumpet Sofiware. Internamunications Corporation has brought three major relecseses over the last two years. Netscape ComNavigator, to market in the pass 12 months, and Microenses of its popular Web browser, Nesccape 298. According to Java developers at Sun Microayutems "(t) Experplorer is keeping pace.

coftware. If just comes when you noed it.... Conlent developers for the Wortd Wide Web iinstalling' to worry about whether or not some special piace of softwere is instulled in a user's there automntically." The Hot Java Browser: 1 White Paper, (on file with the Stanford Law; it just gets also David Bank, The Java Saga, Wireb, Dec. 1995, at 166, 240 (describing the functionaliow) of an carly Jave protolype).

299. Peter H. Lewis, Personal Computers: New World Brought io You by . . ., N.Y. Times, July
30. 1996, at C7. 